\title{
Türkiye'de Emek, Sermaye ve Tüketim Üzerindeki Efektif Vergi Yükü: 2006-2019
}

Birsen NACAR (https://orcid.org/0000-0001-9019-9372), Akdeniz University, Turkey; nacarbirsen@akdeniz.edu.tr

Yakup KARABACAK (https://orcid.org/0000-0002-2185-0237), Akdeniz University, Turkey;

yakupk@akdeniz.edu.tr

\section{Effective Tax Burden on Labour, Capital, and Consumption in Turkey: 2006-} 2019

\begin{abstract}
This article aims to measure the effective tax burden on labour, capital, and consumption in Turkey for the 2006-2019 period. In this study, we use the MRT method to measure the effective tax burden with some improvements. According to this method, the effective tax burden is calculated as tax revenues divided by the associated tax base taken from national accounts. The research results show that the effective tax burden on labour is higher than the effective tax burden on capital and consumption in Turkey. In addition, it turns out that taxes on labour and consumption are more sensitive to economic cycles. However, it is revealed that taxes on capital fluctuate according to changes in tax laws.
\end{abstract}

\section{Keywords \\ : Effective Tax Burden, Effective Average Tax Rate, Implicit Tax Rate, Tax Ratio.}

JEL Classification Codes : $\mathrm{H} 20, \mathrm{H} 22, \mathrm{H} 29$.

\section{$\ddot{\mathbf{O} z}$}

Bu makalenin amacı, Türkiye'de 2006-2019 dönemi için emek, sermaye ve tüketim üzerindeki efektif vergi yükünü ölçmektir. Bu çalışmada efektif vergi yükünü ölçmek için bazı düzeltmelerle MRT metodu kullanılmaktadır. Bu metoda göre, efektif vergi yükü, vergi gelirlerinin ulusal hesaplardan alınan ilişkili vergi matrahına bölünmesiyle elde edilen oran olarak hesaplanmaktadır. Araştırma sonuçları Türkiye'de emek üzerindeki efektif vergi yükünün sermaye ve tüketim üzerindeki efektif vergi yükünden daha yüksek olduğunu göstermektedir. Ayrıca emek gelirleri ve tüketim harcamaları üzerinden alınan vergilerin ekonomik çevrimlere daha duyarlığı olduğu anlaşılmaktadır. Ancak sermaye üzerinden alınan vergilerin ise vergi yasalarında yapılan değişikliklere göre dalgalanma gösterdiği ortaya çıkmaktadır.

Anahtar Sözcükler $\quad$ : Efektif Vergi Yükü, Ortalama Efektif Vergi Oranı, Örtük Vergi Oran1, Vergi Rasyosu. 
Nacar, B. \& Y. Karabacak (2022), “Türkiye'de Emek, Sermaye ve Tüketim

Üzerindeki Efektif Vergi Yükü: 2006-2019”, Sosyoekonomi, 30(51), 487-510.

\section{Giriş}

Maliye teorisinde vergilemenin mali, ekonomik ve sosyal işlevlerinden sıklıkla söz edilir. Ancak vergilemenin söz konusu işlevleri ne derece yerine getirdiğini değerlendirebilmek için makroekonomik faktörler üzerindeki efektif vergi yükünün bilinmesi gerekir. Vergi yükü, vergi gelirinin ilgili vergi matrahına oranını ifade eder (Sørensen, 2004: 2). Ancak efektif vergi yükü hesaplanması vergi beyannamelerinde görülen vergi ve bununla ilişkili vergi matrahlarıyla yapılamaz. Bunun yerine devletin tahsil ettiği vergiler ile söz konusu vergilere kaynaklık eden gelirlerin veya tüketim harcamalarının kullanılması gerekir. Böylece hesaplamaya hem vergi kanunlarında nihai vergi tutarının oluşmasına etki eden parametrelerin hem de ekonomide yaşanan gelişmelerin reel etkileri dahil edilmiş olur (Papageorgiou et al., 2012: 13-14). Literatürde efektif vergi yükü; efektif vergi oran1, ortalama efektif vergi oran1, örtük/zımni vergi oranı ve vergi rasyosu gibi kavramlarla ifade edilmektedir (Volkerink \& De Haan, 2001: 13; European Commission, 2020: 256). Ancak aynı ölçüm tekniğini tanımlamak için kullanılan söz konusu ifadelerin kavram kargaşasına neden olduğu da bir gerçektir. Söz konusu karışıklığı aşmak için bu çalışmada yukarıdaki ifadeler yerine efektif vergi yükü kavramının kullanılması tercih edilmektedir.

Bu çalışmada Türkiye'de 2006-2019 yılları arası dönemde emek, sermaye ve tüketimden oluşan makroekonomik faktörler üzerindeki efektif vergi yükü araştırılmaktadır. Araştırmanın temel amacı, makroekonomik faktörler üzerindeki efektif vergi yükünün dağılımını incelemektir. Türkiye'de makroekonomik faktörler üzerindeki efektif vergi yükünü ölçmek için Mendoza et al. (1994) tarafından geliştirilen ölçüm metodu ${ }^{1}$ temel alınmaktadır. Ancak literatürde MRT metoduna önemli eleştiriler yöneltilmiş ve metot üzerinde bazı düzeltmeler yapılmıştır. Bunlar arasında başlıca Carey \& Tchilinguirian, (2000), Volkerink et al. (2002) ve Carey \& Rabesona (2004) tarafindan yapılan eleştiri ve düzeltmeler sayılabilir. Söz konusu eleştiriler ve düzeltme önerileri çalışmanın literatür incelemesi bölümünde ele alınmaktadır. Ayrıca veri setlerinin yeterince ayrıntılı olmaması da MRT metodolojisinin olduğu gibi uygulanmasına engel teşkil edebilmektedir. Bununla birlikte MRT metodolojinin makroekonomik faktörler üzerindeki efektif vergi yükünü hesaplamaya getirdiği yaklaşım literatürde genel olarak benimsenmiş görünmektedir. Öyle ki yapılan bir çalışmada farklı araştırmacıların orijinal MRT metodu ile düzeltilmiş metotlara göre yapılan ölçümler arasında ihmal edilebilir düzeyde farklar olduğu; hatta bu farkların kullanılan metodolojilerden ziyade, hesaplamaya temel oluşturan veri setlerindeki farklıklardan kaynaklandığı ifade edilmektedir (Martinez-Mongay, 2000: 5, 11, 57). Dolayısıyla bu çalışmada hem literatürde orijinal MRT metodolojinde yapılan düzeltmeler dikkate alınarak hem de kullandığımız veri setinin sağladığı olanaklardan yararlanarak efektif vergi yükü ölçülecektir.

Literatürde Mendoza \& Razin \& Tesar (1994) tarafindan geliştirilen metot, bu çalışmada kısaca MRT metodu olarak kullanılacaktır. 
Türkiye'de makroekonomik faktörler üzerindeki efektif vergi yükü araştırmasına gösterilen ilgi oldukça düşük düzeydedir. Zira yaptığımız literatür taramasında makroekonomik faktörler üzerindeki efektif vergi yükünü ölçen iki çalışmaya ulaşabildik. Bunlardan ilki Ünlükaplan \& Arısoy (2011) tarafından yapılan çalışmadır. Bu çalışma Türkiye'de 1980-2006 yılları arası döneme odaklanmıştır. Diğer çalışma ise Simon \& Harding (2020) tarafından yapılmıştır. Bu çalışmada ise seçilmiş bazı yıllar için sadece tüketim harcamaları üzerindeki efektif vergi yükü hesaplanmıştır. Dolayısıyla Türkiye'de 2006 yılı sonrası dönemde emek, sermaye ve tüketimden oluşan makroekonomik faktörler üzerindeki efektif vergi yükünün ne kadar olduğu hakkında kapsamlı bir araştırma yapılmamış görünmektedir. Dolayısıyla bu çalışmada 2006-2019 yılları arası dönemde emek, sermaye ve tüketim üzerindeki efektif vergi yükü hesaplanarak literatürdeki söz konusu eksikliği gidermeye dönük bir katkı yapılmaktadır.

Bu çalışmada ulaşılan bulgular, 2006-2019 yılları arasında, Türkiye'de emek ve tüketim üzerindeki efektif vergi yükünün sermaye üzerindeki efektif vergi yüküne göre oldukça yüksek olduğunu göstermektedir. Ayrıca tüketim üzerindeki efektif vergi yükünün ekonominin içinde bulunduğu konjonktürden daha fazla etkilendiği görülmektedir. Aynı şekilde ekonomik kriz ve durgunluk dönemlerinde yüksek seyreden işsizlik oranlarının emek üzerindeki efektif vergi yükünün düşmesine sebep olduğu sonucu ortaya çıkmaktadır. Öte yandan sermaye üzerindeki efektif vergi yükünün daha istikrarlı bir seyir izlediği anlaşılmaktadır. Ancak emek ve tüketim üzerindeki efektif vergi yükündeki dalgalanmalar daha çok ekonomik nedenlerle ilişkili iken, sermaye üzerindeki efektif vergi yükündeki küçük çaplı salınımların ise vergi parametrelerinde meydana gelen değişliklerle ilişkili olduğu görülmektedir.

Çalışmanın geri kalanı şu şekilde organize edilmiştir. İlk bölümde makroekonomik faktörler üzerindeki efektif vergi yükünü araştırmış olan çalışmalar incelenmektedir. İkinci bölümde çalışmada kullanılan veri seti ve ölçüm metodu ele alınmaktadır. Üçüncü bölümde ampirik bulgular sunulmaktadır. Dördüncü bölümde ulaşılan bulgular tartışılmaktadır. Son bölümde ise sonuçlara ilişkin genel bir değerlendirme yapılmaktadır.

\section{Literatür İncelemesi}

Efektif vergi yükü araştırmalarını farklı özelliklerine göre tasnif etmek literatürü incelemek için iyi bir başlangıç noktası oluşturabilir. Bu amaçla Tablo 1'de efektif vergi yükü hesaplamalarına ilişkin literatür sınıflandırılarak sunulmaktadır. Bu bağlamda literatür, ileriye doğru (forward-looking) ve geriye doğru (backward-looking) efektif vergi yükü araştırmaları olarak ikiye ayırılabilir. Bunlardan ileriye doğru efektif vergi yükü araştırmaları kullanılan verilerin hipotetik olması nedeniyle tahmini efektif vergi yükü göstergeleri sağlamaktadır. Örneğin vergi kanunlarındaki hükümlerden hareketle yapılan efektif vergi yükü tahminleri böyledir. Geriye doğru efektif vergi yükü hesaplamaları ise gerçek veya gözlemlenebilir verilerle yapılmaktadır. Örneğin devletin fỉilen tahsil ettiği vergi hasılatı istatistikleri ile ulusal hesaplardan alınan bir ekonomik değişken üzerindeki efektif vergi yükünün hesaplanması gibi. Böyle bir hesaplamayı bir firmanın veya sektörün 
gerçek muhasebe verilerinden hareketle de yapmak mümkündür. Bu durumda da geriye doğru efektif vergi yükü göstergeleri hesaplanmış olur (Nicodème, 2001: 6-13).

Tablo: 1

Efektif Vergi Yükü Araştırmalarına İlişkin Literatürün Sınıflandırılması

\begin{tabular}{|c|c|}
\hline $\begin{array}{l}\text { İleriye doğru (ex-ante) efektif vergi yükü hesaplamaları yapan } \\
\text { çalıșmalar. }\end{array}$ & $\begin{array}{l}\text { Geriye doğru (ex-post) efektif vergi yükü hesaplamaları yapan } \\
\text { çalıșmalar. }\end{array}$ \\
\hline $\begin{array}{l}\text { Mikro ölçekli çalışmalar } \\
\text { (Efektif marjinal vergi oranları üretir): }\end{array}$ & $\begin{array}{l}\text { Makro ölçekli çalışmalar } \\
\text { (Ortalama efektif vergi oranları üretir): }\end{array}$ \\
\hline $\begin{array}{l}\text { King \& Fullerton (1984) } \\
\text { OECD (1991) } \\
>\text { Devereux \& Griffith (1999) } \\
\text { Jacobs \& Spengel (1999) }\end{array}$ & $\begin{array}{l}\text { Ulusal Hesaplar Verileri ve OECD Vergi Hasılatı İstatistikleri: } \\
>\text { Mendoza et al. (1994) } \\
>\text { Carey \& Tchilinguirian (2000) } \\
>\text { Volkerink \& De Haan (2002) } \\
>\text { Unlükaplan \& Arısoy (2011) } \\
>\text { Papageorgiou et al. (2012) } \\
>\text { Kostarakos \& Varthalitis (2020) } \\
>\text { European Commission (2020) } \\
>\text { Simon \& Harding (2020) } \\
\text { Firma Verileri: } \\
>\text { Nicodème (2001) } \\
>\text { Clark (2004) }\end{array}$ \\
\hline $\begin{array}{l}\text { Mikro ya da makro ölçekli çalışmalar } \\
\text { (Efektif ortalama vergi oranları üretir) }\end{array}$ & $\begin{array}{l}\text { Mikro ölccekli çalsşmalar } \\
\text { (Marjinal efektif vergi oranları üretir) }\end{array}$ \\
\hline $\begin{array}{l}\text { Devereux \& Griffith (1999); } \\
\text { Jacobs \& Spengel (2002). }\end{array}$ & $\begin{array}{l}\text { Vergi Hasilatı Verileri: } \\
>\text { Gordon et al. (2003). }\end{array}$ \\
\hline
\end{tabular}

Kaynak: Bellak \& Leibrecht (2007:16, Şekil 2.1)’den yararlanarak yazarlar tarafindan oluşturulmuştur.

Öte yandan araştırma ölçeğine göre ise literatür, mikro ve makro ölçekte yapılan çalışmalar olarak tasnif edilebilir. Mikro düzeyde yapılan hesaplamalar temsili bir mükellef veya yatırım tutarı üzerindeki efektif vergi yükünü göstermektedir. Makro ölçekte yapılan araştırmalar ise ulusal ölçekte efektif vergi yükü tahminleri üretmektedir. Bununla birlikte ister mikro isterse makro ölçekte yapılsın, ileriye doğru vergi yükü ölçümleri, ex-ante efektif vergi yükü göstergeleri üretmektedir. Bunun tersine geriye dönük efektif vergi yükü araştırmaları ise mikro ya da makro ölçekte ex-post efektif vergi yükü göstergeleri hesaplamaya imkân vermektedir. Ayrıca mikro ölçekte vergi miktarındaki değişmenin vergi matrahındaki değişmeye oranı olarak marjinal efektif vergi yükü ölçümü de yapılabilmektedir (Jacobs \& Spengel, 1999: 4-6; OECD, 2000: 10-11; Leibrecht \& Römisch, 2002: ii, 4-6). Bu çalışma makro ölçekte gerçek veriler kullanılarak efektif vergi yükünü araştırmayı amaçladığından hem mikro ölçekte yapılan araştırmalar hem de hipotetik verilere dayanan çalışmalar literatür incelememizin dışında bırakılmıştır.

Makro ölçekte ve gerçek veriler kullanılarak efektif vergi yükünü araştıran ilk çalışma Mendoza et al. (1994) tarafından yapılmıştır. Yazarlar 1965-1998 yılları arası dönem için 7 ülkenin verilerini kullanarak devletin emek, sermaye ve tüketim gibi makroekonomik faktörler üzerinden topladığı vergi gelirleri ile ulusal hesaplardan aldıkları gelir ve harcama verilerini kullanarak makro ölçekte emek, sermaye ve tüketim harcamaları üzerindeki efektif vergi yükünü hesaplamışlardır. MRT metodolojisi efektif vergi yükünü devletin fiilen tahsil ettiği vergi hasılatı verileriyle ölçtüğü için vergi yasalarında mevcut olan veya zaman içinde mevzuata eklenen/değiştirilen bütün parametrelerin etkilerinin hesaplamaya dahil edilmesini sağlamaktadır. Aynı şekilde ulusal hesaplardan alınan gelirler ve tüketim harcamaları potansiyel vergi matrahı olarak kullanılarak, ekonomide meydana 
gelen gelişmelerin etkileri de hesaba katılmış olmaktadır (Volkerink \& De Haan, 2001: 14). Bu olumlu özelliklerine rağmen MRT metodolojisinin bazı eksik yönleri de vardır. Örneğin fiyatlar genel seviyesindeki sürekli artışlardan kaynaklanan vergi tahsilatındaki artış (dilim sürüklenmesi, maktu tutarların aşınması) veya azalışlar (verginin doğumuyla tahsilatı arasında geçen süreye bağılı olarak vergi alacağının reel değerinin düşmesi gibi) hesaplamaya dahil edilememektedir.

Carey \& Tchilinguirian (2000) tarafından yapılan çalışmalarda 29 OECD ülkesi için efektif vergi yükü ölçümü yapılmıştır. Carey \& Tchilinguirian (2000)'in MRT metodunu iki temel konuda eleştirdikleri görülmektedir. Bunlardan biri sermaye kazançları üzerindeki efektif vergi yükü hesaplanırken kapital kazançlarına (hisse senedi, bono, tahvil vb.) ilişkin varsayımlarla ilgilidir. Mendoza et al. (1994: 305) sermaye kazançları üzerindeki efektif vergi yükünü hesaplarken ulusal gelir hesaplarından aldıkları işletme artığını vergi matrahı olarak kullanmışlardır. Hâlbuki kapital kazançlarının dayandığı tasarruf araçları katma değer yaratmadığı için ulusal gelir hesaplarında dikkate alınmamaktadır. Bu yüzden Mendoza et al. (1994) sermaye kazançları üzerindeki efektif vergi yükünü gerçekte olduğundan daha düşük hesaplamışlardır (Carey \& Tchilinguirian, 2000: 7). Carey \& Tchilinguirian (2000)'in MRT metodunu eleştirdikleri ikinci husus serbest meslek kazançlarının sermaye kazançlarına dahil edilmiş olmasıyla ilgilidir. Yazarlara göre serbest meslek kazançlarının önemli bir bölümü ücret sayılabilecek emek gelirlerine dayanır. Dolayısıyla hesaplamanın daha gerçekçi olabilmesi için ara bir formülle serbest meslek kazançları üzerinden alınan vergilerin emek ve sermaye kazançları arasında dağıtılması gerekir (Carey \& Tchilinguirian, 2000: 13).

Volkerink et al. (2002) 9 OECD ülkesi için MRT metodunu uygulayarak efektif vergi yükü hesaplaması yapmışlardır. Yazarlar, ulaştıkları bulgulara dayanarak, emek üzerindeki efektif vergi yükünün Kıta Avrupası'nda işsizlik oranlarının artmasında etkili olduğunu, fakat aynı zamanda sermaye üzerindeki efektif vergi yükünün ise ekonomik büyümeyi negatif yönde etkilediğini belirtmektedirler (Volkerink et al., 2002: 221). Ancak yazarların MRT metoduna önemli eleştirileri olmuştur. Bunlardan ilki hane halklarının emek ve sermaye gelirleri üzerinden ödedikleri vergilerin ayrıştırılmasıyla ilgilidir. Mendoza et al. hane hakları için ortalama bir vergi oranı belirleyerek bunu emek ve sermaye gelirleri üzerinden ödenen vergilerin ayrıştırılmasında kullanmıştır (1994: 305). Oysa çeşitli gelir unsurları için vergi sisteminde sağlanan vergi kolaylıkları farklıdır. Keza artan oranlı gelir vergisi tarifesi içinde hane halklarının tümü aynı vergi diliminde vergi ödemezler. Dolayısıyla Mendoza et al. (1994)'nin kullandığ 1 ayrıştırma katsayısı emek ve sermaye gelirleri arasında gelir/kazanç üzerinden ödenen vergilerin dağıtılmasında yanıltıcı sonuçlara neden olabilir.

Ayrıca Volkerink et al. (2002) hane halklarının ödediği vergilere sosyal güvenlik katkılarının da dahil edilmesi gerektiğini söylerler. Öte yandan yazarlar emek üzerindeki efektif vergi yükü hesaplanmasında Mendoza et al. (1994)'den farklı olarak formülün paydasına işgücü ödemelerini koyarlar. Böylece hesaplama tüm emek gelirlerini kapsayacak şekilde genişletilmiş olur. Ancak harcama üzerinden alınan vergi yükünün hesaplanmasında 
Nacar, B. \& Y. Karabacak (2022), “Türkiye'de Emek, Sermaye ve Tüketim

Üzerindeki Efektif Vergi Yükü: 2006-2019”, Sosyoekonomi, 30(51), 487-510.

oldukça hatalı bir biçimde hane halkları nihai tüketim harcamalarının yanı sıra devletin tüketim harcamalarını da ölçüme dahil etmişlerdir (Volkerink et al., 2002: 212). Oysa birçok ülkede devletin kamu personeli için yaptığı maaş ve ücret ödemeleri katma değer vergisinin kapsamı dışındadır. Bu yüzden Volkerink et al. (2002)'nin tüketim üzerindeki efektif vergi yükü hesaplaması olduğundan daha küçük hesaplanma riskiyle karşı karşıyadır.

Carey \& Rabesona (2004) MRT metodunu kullanarak 25 OECD ülkesi için efektif vergi yükü ölçümü yapmışlardır. Ancak Carey \& Rabesona (2004) MRT metodu üzerinde bazı değişiklikler yapmışlardır. Bunlardan biri Mendoza et al. (1994) çalışmalarında emek üzerinden alınan vergiler arasında sayılan sosyal güvenlik katkılarının emek ve sermaye arasında ayrıştırılmasıdır. Bu tercih emek gelirleri üzerinden alınan vergi miktarının düşmesine neden olmuştur. Öte yandan Carey \& Rabesona (2004) potansiyel vergi matrahı olan ücret ve maaş gelirlerine parafiskal gelirler ile işgücü üzerindeki diğger vergileri de ekleyerek emek gelirleri üzerindeki efektif vergi yükünü hesaplamak için kullanılan potansiyel vergi matrahını (paydayı) büyütmüşlerdir. Bunun sonucunda Mendoza et al. (1994) tarafından hesaplanan emek gelirleri üzerindeki efektif vergi yüküne göre Carey \& Rabesona (2004)'nın hesapladıkları emek gelirleri üzerindeki efektif vergi yükü daha düşük çıkmıştır. Carey \& Rabesona (2004)'nın sermaye kazançları üzerindeki efektif vergi yükünü hesaplarken yaptıkları düzeltmeler ise sermaye kazançları üzerindeki efektif vergi yükünün Mendoza et al. (1994)'nin çalışmalarında ulaştıkları sonuçlara göre daha yüksek çıkmasına neden olmuştur. Zira yazarlar hem sosyal güvenlik işveren katkılarını hem de taşınmaz varlıklar üzerinden alınan vergileri sermaye kazançları üzerinden alınan vergilere eklemişlerdir (Carey \& Rabesona, 2004: 217, 250).

Ünlükaplan \& Arısoy (2011) Türkiye'de 1980-2006 yılları için hane halkı gelirleri, emek, sermaye ve tüketim harcamaları üzerindeki efektif vergi yükünü hesaplamışlardır. Yazarlar üç farklı ölçüm metodu kullanmışlardır. Bunlardan ilki orijinal MRT metodudur. Diğer ikisi ise MRT metodunun Carey \& Rabesona (2004) tarafından düzeltilmiş sürümleridir. Ünlükaplan ve Arısoy (2011)'un bulguları incelendiğinde Carey \& Rabesona metodolojisine göre yapılan her iki hesaplamada efektif vergi yükü sonuçları arasında dikkate değer büyüklükte bir fark yoktur. Ancak MRT metodolojisi ile Carey \& Rabesona metodolojisine göre yapılan hesaplamalarda ise özellikle tüketim üzerindeki efektif vergi yükü sonuçlarında bariz farklılıklar göze çarpmaktadır. Bununla birlikte işgücü, hane halkı gelirleri ve sermaye üzerindeki efektif vergi yükü ise her üç metodolojide de birbirine oldukça yakın görünmektedir. Sadece sermaye üzerindeki efektif vergi yükü 1999 yılından sonra Carey \& Rabesona metodolojisine göre yapılan hesaplamalarda daha büyük çıkmaya başlamıştır. Ayrıca Ünlükaplan \& Arısoy tarafından yapılan ölçümler Türkiye'de emek gelirleri üzerindeki vergi yükünün her üç metoda göre de sermaye ve tüketim üzerindeki efektif vergi yükünden daha fazla olduğunu göstermektedir (2011: 21-22, Tablo 4, 5, 6).

Papageorgiou et al. (2012) Yunanistan'da 2000-2009 y1lları arası dönemde efektif vergi yükünü araştırmışlardır. Yazarlar efektif vergi yükünü ölçmek için MRT metodolojisini takip etmişlerdir. Söz konusu çalışmada emek, sermaye, tüketim, serbest meslek kazançları, kurum kazançları ile sosyal güvenlik katkıları (bağımlı çalışanlar, 
Nacar, B. \& Y. Karabacak (2022), “Türkiye'de Emek, Sermaye ve Tüketim Üzerindeki Efektif Vergi Yükü: 2006-2019”, Sosyoekonomi, 30(51), 487-510.

işverenler ve kendi adına çalışanların sosyal güvenlik katkıları ayrı ayrı ele alınmıştır) için efektif vergi yükü tahminleri yapılmıştır. Ulaşılan sonuçlar yazarlar tarafından Euro bölgesi ülkeleri için yapılan hesaplamada ulaşılan ortalama efektif vergi yükü göstergeleri ile karşılaştırılmıştır. Araştırma sonuçları Yunanistan'da emek ve sosyal güvenlik katkıları için hesaplanan efektif vergi yükünün oldukça yüksek olduğunu, ancak tüketim üzerindeki efektif vergi yükünün ise bariz biçimde düşük olduğunu ortaya koymaktadır. Ayrıca Euro bölgesiyle Yunanistan karşılaştırıldığında özellikle serbest meslek kazançlarında Yunanistan'ın daha yüksek efektif vergi yükü göstergesine sahip olduğu ifade edilmektedir.

Kostarakos \& Varthalitis (2020) 1995-2017 yılları arası dönem için İrlanda ve 27 AB üyesi ülke (Hırvatistan hariç) verilerini kullanarak efektif vergi yükünü araştırmışlardır. Orijinal MTR metodolojisini takip eden yazarlar emek, sermaye, tüketim ve kurumlar üzerindeki efektif vergi yükünü hesaplamışlardır. Bunun yanında aynı dönem için İrlanda ve 27 Avrupa Birliği ülkesi ortalaması olarak sosyal sigorta katkıları ile birleşik emek ve tüketim harcamaları için efektif vergi yükü ölçmüşlerdir. Yazarların İrlanda için ulaştıkları bulgular, üretim faktörleri üzerindeki bozucu etkileri daha yüksek vergilerin (emek ve sermayeden alınan vergiler) nispeten daha düşük olduğunu, ancak tüketim üzerinden alınan ve bozucu etkileri görece daha düşük vergilerin ise daha yüksek efektif vergi yükü büyüklügüne sahip olduğunu göstermektedir. Ancak 27 AB ülkesi ortalaması olarak ulaşılan bulgular İrlanda için yukarıda ifade edilen efektif vergi yükü göstergelerinin tam tersi bir sonuca işaret etmektedir. Yapılan karşılaştırmalarda 27 AB ülkesinin emek ve sermaye gibi üretim faktörleri üzerindeki vergilerin İrlanda'dan daha fazla olduğu, ancak tüketim üzerindeki vergilerde ise İrlanda'nın 27 AB ülkesinin efektif vergi yükü ortalamasından daha yüksek olduğu sonucuna ulaşılmıştır.

European Commission (2020) 28 Avrupa Birliği üyesi ülke ile İzlanda ve Norveç’i de kapsayan çalışmalarında emek, sermaye, tüketim, kurum kazançları, enerji ve çevre vergileri için efektif vergi yükü ölçümleri yapmıştır. 2006-2018 yıllarını kapsayan söz konusu çalışmada MRT metodu belli konularda değiştirilerek uygulanmıştır. Kullanılan metotlar arasındaki önemli fark, gelir vergisinin emek ve sermaye arasında ayrıştırılması noktasında ortaya çıkmaktadır. Mendoza et al. (1994) toplam gelir vergisi hasılatını maaş, ücret, mülk ve girişim gelirleri ile kurumsal olmayan işletme gelirleri toplamına bölerek hane halklarının ortalama vergi oranını hesaplamışlardır. Literatürde bu oran farklı vergi matrahlarına tabi olanlar ile çeşitli vergi kolaylıklarından faydalananlar arasında ayrım yapmadığı için gerçekçi olmadığ1 yönünde eleştirilmiştir. European Commission (2020: 287) ise ücret gelirlerini (W) toplam kişisel gelirlere (Y) oranlayarak bulduğu emek pay1 katsayısı ile kişisel gelir vergisi hasılatından emek ve sermaye gelirleri üzerinden ödenen payları ayrıştırmaktadır. Bu ayrıştırma yöntemi de en az Mendoza et al. (1994)'nin uyguladıkları hesaplama metodu kadar genel bir katsayı olmaktadır. Öte yandan European Commission (2020) tüketim üzerindeki efektif vergi yükünü ölçerken sadece nihai hane halkı tüketim harcamalarını esas almıştır. Ayrıca tüketim vergilerinin sınıflandırmasında da Mendoza et al. (1994) tarafından kullanılan metoda uygun davranmamıştır. Dolayısıyla European Commission (2020)'un tüketim üzerindeki efektif vergi yükü Mendoza et al. (1994)'nin ölçümlerine göre daha büyük çıkma eğilimindedir. Zira European Commission 
(2020) tüketim vergilerinin potansiyel matrahını olduğundan daha küçük bir değer olarak hesaplamaya almıştır. European Commission ölçümlerine göre 2018 yılında 28 Avrupa Birliği üyesi ülkenin emek üzerindeki efektif vergi yükü \%36,3 olarak hesaplanmıştır. Aynı yıl tüketim üzerindeki efektif vergi yükü \%16,9 ve sermaye üzerindeki efektif vergi yükü ise \%21,2 olarak tahmin edilmiştir (European Commission, 2020: 28, 29, 33).

Simon \& Harding (2020) ise OECD ülkelerini esas alarak 1995-2017 yılları arası tüketim üzerindeki efektif vergi yükünü hesaplamıştır. Yazarlar MRT ölçüm metodunu takip etmişlerdir. Dolayısıyla Simon \& Harding (2020) tarafından yapılan ölçümler tüm harcama vergileri ve hane halkları nihai tüketim harcamaları, kâr amacı gütmeyen kurumların nihai tüketim harcamaları ve devletin kamu çalışanları maaş ve ücretleri hariç nihai tüketim harcamalarını kapsamaktadır. Ayrıca harcamalar toplamından MRT metoduna uygun olarak harcama vergileri düşülerek net harcamalara ulaşılmıştır (Simon \& Harding, 2020: 19). Yazarlar ekonomide yaşanan gerilemenin tüketim üzerinden alınan vergileri nasıl etkilediğini saptayabilmek için OECD ülkelerindeki tüketim harcamaları üzerindeki efektif vergi yükünü hesaplamışlardır. Ayrıca katma değer vergisi verimliliğindeki ve katma değer vergisi oranlarındaki değişikliklerin efektif vergi yükü üzerindeki etkilerini araştırmışlardır. Böylece OECD üyesi ülkelerde tüketim üzerinden alınan vergi gelirlerinde gözlemlenen istikrarın hem tüketim harcamaları hem de vergi parametrelerindeki değişikliklerinden kaynaklandığı sonucuna varmışlardır (Simon \& Harding, 2020: 39-40).

\section{Veri Seti ve Ölçüm Metodu}

\subsection{Veri Seti}

Bu çalışmada iki farklı veri seti kullanılmaktadır. Bunlardan ilki vergi, harç ve sosyal güvenlik gelirlerine ilişkin mali istatistiklerdir. İkincisi ise ulusal hesaplar gayri safi yurt içi hâsıla tahmini verileridir. 2006-2019 yılları arası dönem için vergi, harç ve sosyal güvenlik gelirlerine ilişkin veriler, Hazine ve Maliye Bakanlığı (2020a; 2020b; 2020c; 2020d), Sosyal Güvenlik Kurumu (2020) ve Türkiye İş Kurumu (2020) mali istatistiklerinden alınmıştır. Söz konusu kamu gelirlerinin tasnifinde genel yönetim bütçe gelirleri (Ekod4) sınıflandırması esas alınmıştır. Ancak genel yönetim bütçe sisteminde (2000) sınıflandırma koduyla izlenen sosyal güvenlik prim gelirleri bağımlı (ücret ve maaş karşılığı çalışanlar) ve bağımsız (kendi işinde çalışanlar veya çalışmayanlar) istihdam edilenler açısından yeniden sınıflandırmayı gerektirmektedir. Bu nedenle veri setinde sosyal güvenlik primlerinin alt kalemlerinden yararlanarak bağımlı çalışanların ödediği sosyal güvenlik primleri (2000a) sınıflandırma koduyla; bağımsız istihdam kapsamında kalanların ödediği sosyal güvenlik primleri ise (2000b) sınıflandırma koduyla gösterilmektedir. Ayrıca çalışanların ödediği sosyal güvenlik primlerine işveren hissesi de eklenmiştir. Ancak sosyal güvenlik kurumlarına devlet katkısı veri seti dışında bırakılmıştır. Zira sosyal güvenlik kurumlarına devlet katkısı bir gelir kalemi değil bir kamu transfer harcamasıdır. Genel yönetim bütçe sınıflandırmasında yer almayan işsizlik sigortası fonu prim gelirleri (devlet katkısı hariç) ise veri setine ayrıca eklenmiştir. Tablo 2'de vergi, harç, sosyal güvenlik katkısı ve işsizlik sigortası prim gelirlerine ilişkin verilerin tasnifi sunulmaktadır. 
Nacar, B. \& Y. Karabacak (2022), “Türkiye'de Emek, Sermaye ve Tüketim

Üzerindeki Efektif Vergi Yükü: 2006-2019”, Sosyoekonomi, 30(51), 487-510.

Tablo: 2

\section{Vergi, Harç, Sosyal Güvenlik Katkıları ve İşsizlik Sigortası Fonu Kesintilerinin Sınıflandırılması}

\begin{tabular}{|c|c|c|c|c|}
\hline \multicolumn{4}{|c|}{ Sinıflama Kodları } & \multirow{2}{*}{$\begin{array}{l}\text { Gelir Türleri } \\
\text { Vergi Gelirleri } \\
\end{array}$} \\
\hline 1 & 0 & 0 & 0 & \\
\hline 1 & 1 & 0 & 0 & Gelir, Kar ve Sermaye Kazançları Üzerinden Alınan Vergiler \\
\hline 1 & 1 & 1 & 0 & Gelir Vergisi \\
\hline 1 & 1 & 1 & 3 & Gelir Vergisi Tevkifatı \\
\hline 1 & 1 & 1 & $3 a$ & Maaș ve Ücretlerden Kaynakta Kesinti Yoluyla Tahsil Edilen Gelir Vergisi \\
\hline 1 & 1 & 2 & 0 & Kurumlar Vergisi \\
\hline 1 & 2 & 0 & 0 & Mülkiyet Üzerinden Alınan Vergiler \\
\hline 1 & 2 & 1 & 0 & Veraset ve İntikal Vergisi \\
\hline 1 & 2 & 2 & 0 & Motorlu Taşıtlar Vergisi \\
\hline 1 & 2 & 9 & 0 & Mülkiyet Üzerinden Alınan Diğer Vergiler \\
\hline 1 & 2 & 9 & 51 & Bina Vergisi \\
\hline 1 & 2 & 9 & 52 & Arsa Vergisi \\
\hline 1 & 2 & 9 & 53 & Arazi Vergisi \\
\hline 1 & 2 & 9 & 54 & Çevre Temizlik Vergisi \\
\hline 1 & 3 & 0 & 0 & Dahilde Alınan Mal ve Hizmet Vergileri \\
\hline 1 & 3 & 1 & 0 & Dahilde Alınan Katma Değer Vergisi \\
\hline 1 & 3 & 2 & 0 & Özel Tüketim Vergisi \\
\hline 1 & 3 & 3 & 0 & Banka ve Sigorta Muameleleri Vergisi \\
\hline 1 & 3 & 4 & 0 & Șans Oyunları Vergisi \\
\hline 1 & 3 & 5 & 0 & Özel İletişim Vergisi \\
\hline 1 & 3 & 9 & 0 & Dahilde Alınan Diğer Mal ve Hizmet Vergileri \\
\hline 1 & 3 & 9 & 1 & 6113 sayılı Kanun Kapsamında Alınan Vergiler \\
\hline 1 & 3 & 9 & 51 & Eğlence Vergisi \\
\hline 1 & 3 & 9 & 52 & Yangin Sigortas1 Vergisi \\
\hline 1 & 3 & 9 & 53 & İlan ve Reklam Vergisi \\
\hline 1 & 4 & 0 & 0 & Uluslararası Ticaret ve Muamelelerden Alınan Vergiler \\
\hline 1 & 4 & 1 & 0 & Gümrük Vergileri \\
\hline 1 & 4 & 1 & 1 & Gümrük Vergileri \\
\hline 1 & 4 & 1 & 2 & Ek Mali Yükümlülük \\
\hline 1 & 4 & 2 & 0 & İthalde Alınan Katma Değer Vergisi \\
\hline 1 & 4 & 3 & 0 & Diğer Dış Ticaret Gelirleri \\
\hline 1 & 5 & 0 & 0 & Damga Vergisi \\
\hline 1 & 5 & 1 & 0 & Damga Vergisi \\
\hline 1 & 5 & 2 & 0 & Eğitime Katk1 Pay1 Ayrılması Gereken Damga Vergisi \\
\hline 1 & 6 & 0 & 0 & Harçlar \\
\hline 1 & 9 & 0 & 0 & Bașka Yerde Sinıflandırılmayan Vergiler \\
\hline 1 & 9 & 1 & 0 & Kaldırılan Vergi Artıkları \\
\hline 1 & 9 & 2 & 0 & Bazı Varlıkların Milli Ekonomiye Kazandırılması. Hakkındaki Kanunu U. Alınan Vergiler \\
\hline 1 & 9 & 9 & 0 & Bașka Yerde Sinıflandırılmayan Diğer Vergiler \\
\hline 2 & 0 & 0 & 0 & Sosyal Güvenlik Prim Gelirleri \\
\hline 2 & 1 & 0 & 0 & Sosyal Sigortalar Prim Gelirleri \\
\hline 2 & 1 & 1 & 0 & Malullük, Yasslılık ve Ölüm Sigortası Prim Gelirleri \\
\hline 2 & 1 & 1 & 2 & Bağımsız Çalıșanlardan veya Çalıșmayanlardan Prim Gelirleri \\
\hline 2 & 2 & 0 & 0 & Genel Sağlık Sigortası Prim Gelirleri \\
\hline 2 & 2 & 1 & 2 & Bağımsız Çalışanlardan veya Çalışmayanlardan Alınan GSS Prim Gelirleri \\
\hline 2 & 2 & 1 & 4 & Primi Devletçe Karșlanan GSS Primi Gelirleri \\
\hline 2 & 3 & 0 & 0 & İș Kazaları ve Meslek Hastalıkları Prim Gelirleri \\
\hline 2 & 3 & 1 & 2 & Bağımsız Çalışanlardan ve Çalışmayanlardan Al. İş K. ve M. H. Prim Gelir \\
\hline 2 & 4 & 0 & 0 & Diğer Sosyal Güvenlik Prim Gelirleri \\
\hline 2 & 5 & 0 & 0 & Devlet Katkıs1 \\
\hline 2 & 6 & 0 & 0 & 5510 Öncesi Sosyal Sigorta Prim Gelirleri \\
\hline 2 & 6 & 1 & 2 & Bağımsız Çalıșanlardan veya Çalıșmayanlardan Alınan Prim Gelirleri \\
\hline 2 & 0 & 0 & $0 \mathrm{a}$ & Bağımlı İstihdam Edilenler $(2112+2212+2312+2612+2214+2500$ hariç $)$ \\
\hline 2 & 0 & 0 & $0 \mathrm{~b}$ & Bağımsız İstihdam Edilenler veya Çalışmayanlar $(2112+2212+2312+2612)$ \\
\hline 2 & 9 & 0 & 0 & İsșizlik Sigortası Fonu Primleri (Devlet Katkısı Hariç) \\
\hline
\end{tabular}

Kaynak: Hazine ve Maliye Bakanllğı (2020a)'dan faydalanarak tarafimızdan düzenlenmiştir.

$\mathrm{Bu}$ çalışmada faydalandığımız makroekonomik değişkenler Tablo 3'te sunulmaktadır. Tablo 3'teki ulusal hesaplara ilişkin değişkenler ile büyüme ve işsizlik oranları Türkiye İstatistik Kurumu (2020) veri tabanından alınmıştır. Devletin kamu 
personel ücretlerine ilişkin yaptığı harcamaları (GW) Hazine ve Maliye Bakanlığı (2020b) genel yönetim bütçe giderlerinden alınmıştır. Ancak 2006-2010 yılları kamu personeli maaş ve ücret ödemeleri Merkezi yönetim ve yerel yönetimler bütçelerinden alınan harcama kalemleri toplamından oluşmaktadır. Sosyal güvenlik kurumları personel giderleri 20062010 yılları arasında kamu personel giderlerine dahil değildir. Öte yandan ücret ve maaş gelirlerinden yapılan gelir vergisi tevkifat oranları ise Gelir İdaresi Başkanlığı (2006-2018) yıllık faaliyet raporlarından derlenmiştir. Söz konusu yıllık faaliyet raporlarında kesinti yoluyla ödenen vergilere ilişkin muhtasar beyanname özetleri bulunmaktadır. Faaliyet raporlarında ücretler başta olmak üzere yedi gelir unsurunun her birine ilişkin kesinti oranlarını bulmak mümkündür. Tablo 3'te görülen semboller literatüre uyum sağlamak amacıyla İngilizce terimlerin kısaltmalarından oluşmaktadır.

Tablo: 3

\section{Makro Ekonomik Değişkenler ve Sembolleri}

\begin{tabular}{|l|l|}
\hline CoE & İşgücü Ödemeleri \\
\hline Net OS & Net İşletme Artığı \\
\hline C & $\begin{array}{l}\text { Hane Halklarının Nihai Tüketim Harcamaları ile Hane Halkına Karşlıksız Yardım Eden } \\
\text { Kâr Amacı Gütmeyen Kurumların Nihai Tüketim Harcamaları }\end{array}$ \\
\hline GC & Devlet Nihai Tüketim Harcamaları \\
\hline GW & Devletin kamu çalışanları için ödediği maaş ve ücretler harcamaları \\
\hline T & Ücret ve Maaş Gelirlerinden Yapılan Gelir Vergisi Kesintisi Payı (\%) \\
\hline GR & Büyüme Oranı \\
\hline UE & İşsizlik Oranı \\
\hline
\end{tabular}

Kaynak: Ulusal hesap verileri TÜIK (2020a; 2020b; 2020c; 2020d)'den, ücretlerden gelir vergisi kesintisi oranlarl ise Gelir İdaresi Başkanlığı, (2006-2020) Yıllık Faaliyet Raporlarından alınmıştır.

\section{2. Ölçüm Metodu}

Bu bölümde öncelikle MRT metodunun kuramsal çerçevesi sunulmaktadır. Ardından söz konusu ölçüm metodundan faydalanarak oluşturduğumuz hesaplama metodu açıklanmaktadır.

\subsubsection{Mendoza, Razin ve Tesar Metodu}

Mendoza et al. (1994) vergi yükünü değer (ad-valorem) olarak ölçerler. Yazarlar ölçüm metodunu geliştirirken üç maldan (emek, sermaye, tüketim) oluşan bir ekonomi soyutlaması yapmışlardır. Ardından her bir malın vergi öncesi fiyatı ile vergi sonrası fiyatı arasındaki farkı ad-valorem vergi yükü olarak tarif etmişlerdir (Mendoza et al., 1994: 301302). Mendoza et al. (1994: 304-306) mikro ölçekte temsili üç mal için kurdukları modeli daha sonra makro ölçekte emek, sermaye ve tüketim üzerinden toplanan vergilere uygulamışlardır. Vergi yükünün makro ölçekte hesaplanması emek, sermaye ve tüketim üzerinden alınan vergilerle söz konusu vergilere kaynaklık eden vergi matrahlarının toplulaştırılmış olarak ele alınmasını gerektirmektedir. Mendoza et al. (1994) ölçüm için kullandıkları vergi hasılatlarını OECD veri setinden çekmişlerdir. Kavramsal olarak tanımladıkları vergi matrahlarını ise ulusal hesaplardan almışlardır. Dolayısıyla Mendoza et al. (1994)'nin kullandığı vergi matrahları vergi beyannamelerinde görünen vergi matrahları değildir. Onun yerine potansiyel vergi matrahı olarak makroekonomik değerler 
kullanılmıştır. Mendoza et al. (1994) vergi yükünü değer olarak ölçmelerine rağmen efektif vergi yükünü oran (rasyo) biçiminde ifade etmişlerdir.

Burada ilk olarak Mendoza et al. (1994)'nin tüketim üzerindeki vergi yükü ( $\tau$ con) hesaplama metodu ele alınmaktadır. Yazarlar tüketim üzerindeki ad-valorem vergi yükünü tüketimin vergi öncesi değeri ile vergisi sonrası değeri arasındaki fark olarak tanımlamışlardır. Bu bağlamda devletin tahsil ettiği tüketim vergileri ad-valorem vergi yükünü göstermektedir. Vergi yükünün dayandığı vergi matrahı ise söz konusu vergilerin dahil edilmediği harcamalardan oluşmaktadır. Aşağıdaki formül (1)'de tüketim üzerindeki efektif vergi yükünün oransal (rasyo) ifadesi gösterilmektedir.

$$
\tau \text { con }=\left[\frac{(5110+5121)}{C+G-G W-(5110+5121)}\right] \times 100
$$

Formül (1)'de payda yer alan vergiler OECD siniflandırma kodlarıyla ifade edilmiştir. Söz konusu vergilerden ilki mal ve hizmetler üzerindeki genel vergileri (5110) ikincisi ise gider vergilerini (5121) göstermektedir. Formül (1)'in paydasında yer alan kavramsal vergi matrahı ise hane halkları nihai tüketim harcamaları (C) ile devletin nihai tüketim harcamalarından $(G)$ toplamından oluşmaktadır. Ancak yazarlar harcama vergilerine tabi bir gider olmadıkları için devlet bütçesinden kamu çalışanları için ödenen maaş ve ücretleri $(\mathrm{GW})$ devletin nihai tüketim harcamalarından düşmüşlerdir. Keza tüketimin vergi öncesi değerini kullanmak maksadıyla payda yer alan tüketim vergileri $(5110+5121)$ de paydadaki tüketim tutarından düşülmüştür.

Mendoza et al. (1994) emek üzerindeki efektif vergi yükünü hesaplamak için iki ayrı formül oluşturmuştur. Bunlardan ilki hane halklarının ödediği gelir vergisi efektif vergi yüküdür $(\tau$ h). Burada devletin hane halklarından topladığı gelir vergisi hasılatı vergi yükünün ad-valorem tutarını göstermektedir. Söz konusu vergi yüküne dayanak teşkil eden kavramsal vergi matrahı ise hane halklarının (gerçek kişilerin) çeşitli gelir, kazanç ve iratları toplamından oluşmaktadır. Aşağıdaki formül (2)'nin payında yer alan gelir vergisi OECD vergi sınıflandırma koduyla ifade edilen gerçek kişilerden alınan gelir vergisini göstermektedir. Formülün paydasında yer alan gelir türleri ise sırasıyla ücretler (W), gerçek kişilere ait firmaların işletme artığı (OSPUE) ile hane halklarının ücret ve girişim dışında kalan (kira, faiz vb.) gelirleri (PEI) toplamından oluşmaktadır.

$$
\tau h=\left[\frac{1100}{W+O S P U E+P E I}\right] \times 100
$$

Yukarıdaki formül (2)'nin sonucu hane halklarının efektif gelir vergisi yükünü ( $\tau$ h) gösterir. Ancak formül (2)'ye göre hesaplanan efektif vergi yükü hane halkının emek gelirleri ya da sermaye gelirleri üzerindeki vergi yükünü açıklamaya yetmez. Zaten Mendoza et al. (1994)'nin buradaki asıl amacı hane halklarının gelir vergisinden kaynaklanan efektif vergi yükünü ölçmek değildir. Yazarlar hane halklarının emek ve sermaye gelirleri üzerinden ödedikleri vergileri hesaplayabilmek için formül (2)'de ifade edilen hane halkı vergi yükü ( $\tau$ h) ölçümünü yapmışlardır. Mendoza et al. (1994)'e göre 
ekonomide hane halklarının emek ve sermaye gelirleri bilindiğinde, söz konusu oran uygulanarak gelir vergisi hasılatı emek ve sermaye üzerinden alınan gelir vergi payına ayrıştırılabilir.

Mendoza et al. (1994)'ne göre emek üzerindeki vergiler; ücret gelirleri üzerinden hane halkları ortalama gelir vergisi oranına $(\tau$ h) göre hesaplanan gelir vergisi $(\tau \mathrm{h} . \mathrm{W})$, sosyal güvenlik primleri (2000) ile maaş ve ücret bordroları üzerinden kesilen diğer vergiler (3000) toplamından oluşur. Emek gelirleri üzerinden alınan vergilerin kavramsal matrahı ise toplam ücretlere (W) sosyal güvenlik primleri işveren hissesinin (2200) eklenmesiyle bulunan değerdir. Söz konusu verilerden hareketle, Mendoza et al. emek üzerindeki efektif vergi yükü ölçümünü aşağıda formül (3)’de görüldüğü gibi ölçmüşlerdir (1994: 305).

$$
\tau l a b=\left[\frac{(\tau h . W+2000+3000)}{W+2200}\right] \times 100
$$

Mendoza et al. (1994) sermayeden alınan vergilerin ise gerçek kişilere ait firmaların işletme atığı (OSPUE) ile hane halklarının ücret ve girişim dışında kalan (kira, faiz vb.) gelirleri (PEI) üzerinden hane halkları ortalama gelir vergisi oranına ( $\tau$ h) göre hesaplanan gelir vergisi, kurumlara vergisi (1200), taşınmaz varlıklar üzerinden alınan servet vergileri (4100), sermaye intikalleri üzerinden alınan vergilerden (4400) oluştuğunu varsaymışlardır. Kavramsal olarak işletme artığını (OS) ise sermaye üzerinden alınan vergilerin matrahı olarak kabul etmiştir. Söz konusu verilerden hareketle Mendoza et al. (1994)'nin sermaye üzerindeki efektif vergi yükünü ölçmek için geliştirdikleri formül ise şu şekildedir:

$$
\tau \text { cap }=\left[\frac{(\tau h \cdot(\text { OSPUE }+P E I)+1200+4100+4400)}{O S}\right] \times 100
$$

Çalışmanın takip eden bölümünde Mendoza et al. (1994) tarafından geliştirilen formüllerde (özellikle 1, 3 ve 4 no'lu formüllerde) yapılan düzeltmeleri açıklayarak, Türkiye'de emek, sermaye ve tüketim üzerindeki efektif vergi yükü hesaplamak için kullanılan formüller ortaya konulmaktadır.

\subsubsection{Emek Üzerindeki Efektif Vergi Yükü}

Emek üzerindeki efektif vergi yükünü hesaplayabilmek için öncelikle ücret, maaş, yevmiye gibi emek gelirleri üzerinden alınan dolaysız vergilerin tasnif edilmesi gerekir. Ücret ve maaş gelirleri üzerinden alınan vergilerin en başında gelir vergisi vardır. Ancak gelir vergisi çeşitli gelir unsurlarından alındığ gelir vergisi payına ilişkin ayrıntılı veri bulunmamaktadır. Bu nedenle ilkin ücret ve maaşlar üzerinden alınan gelir vergisi tutarının belirlenmesi gerekir. Mendoza et al. (1994) yukarıda formül (2) ifade edildiği gibi hane halkları ortalama gelir vergisi ( $\tau$ h) oranına göre ücret ve maaşlar üzerinden alınan gelir vergisini hesaplamışlardır. Ancak bu hesaplama biçimi her bir mükellefin aynı oranda vergi istisna ve muafiyetlerinden yararlandığını örtük olarak varsayar. Aynı zamanda gelir veya iratların gelir vergisi tarifesinin farklı dilimlerine göre vergilendirildiği gerçeğini de görmezden gelir. Dolayısıyla hane halkları gelir vergisi oranı 
( $\tau$ h) emek ve sermaye üzerinden alınan gelir vergisinin doğru bir ölçüsünü vermekten uzaktır.

$\mathrm{Bu}$ nedenle yukarıda bahsi geçen hesaplama metodundan farklı bir yol izleyerek Türkiye'de emek üzerinden alınan gelir vergisi tutarı hesaplanmıştır. Ülkemizde gelir vergisi tahsilatının yaklaşık \%90'1 kaynakta kesinti yoluyla tahsil edilmektedir. Kaynakta tevkif yoluyla tahsil edilen gelir vergisi payları Gelir İdaresi Başkanlığı yıllık faaliyet raporlarında sunulan muhtasar beyanname özetlerinde mevcuttur. Bu çalışmada muhtasar beyanname özetlerinde sunulan maaş ve ücretlerden yapılan gelir vergisi kesinti payı, emek gelirleri üzerinden ödenen gelir vergisi olarak kabul edilmektedir. Muhtasar beyanname özetlerindeki ücret ve maaşlardan kesilen gelir vergisi payına $(\mathrm{T})$ göre veri setimizde (1113) sınıflandırma koduyla görülen kaynakta tevkif yoluyla tahsil edilmiş gelir vergisi hasılatı iki alt bölüme ayrılmaktadır. Veri setinde (1113a) sınıflandırma koduyla görülen vergi tutarı, ücret gelirleri üzerinden alınan gelir vergisini göstermektedir ${ }^{2}$. Bu vergi tutarı aşağıda formül (5)'in payına emek üzerinden alınan gelir vergisi olarak eklenmiştir.

$$
\tau \text { Emek }=\left[\frac{(1113 a+2000 a+2900)}{\operatorname{CoE}}\right] \times 100
$$

Emek üzerinden alınan ikinci önemli vergi kalemi ise sosyal güvenlik primleridir. Veri setinde bağımlı ve bağımsız istihdam edilenler bakımından ikiye ayırdığımız sosyal güvenlik primlerine devlet katkısı dahil değildir. Burada bağımlı istihdam edilenlerin ödediği sosyal güvenlik primleri esas alınmaktadır. Ancak bağımlı istihdam edilenlerin ödediği sosyal güvenlik primlerine (2000a) muhasebe sisteminde işveren hissesi olarak izlenen sosyal güvenlik primleri de dahildir. Her ne kadar işveren hissesi olarak adlandırılsa da gerçekte söz konusu sosyal güvenlik primleri ücret maliyetlerinin bir parçası olarak çalışan kişiler tarafindan ödenmektedir.

Emek gelirleri üzerinden ödenen vergilere eklenen son kalem ise işçi statüsünde çalışanlar tarafından ödenen işsizlik sigortası fonu primleridir. Söz konusu primlere devlet katkısı dahil değildir. Ancak işsizlik sigortası fonu işveren hissesi dahildir. Zira yukarıda belirtildiği gibi işsizlik sigortası fonu primleri de ücret maliyetinin bir parçası olarak çalışan kişi tarafından ödenmektedir. Yukarıdaki formül (5)'in payında görülen vergiler emek üzerinden alınan vergileri göstermektedir ${ }^{3}$. Paydada ise ulusal gelir hesaplarından alınan işgücü ödemeleri (CoE) bulunmaktadır. Söz konusu formül (5) emek üzerindeki efektif vergi yükünü göstermektedir. Paydada yer alan işgücü ödemeleri ücret ve maaşlar üzerinden tahsil edilen dolaysız vergilerin tümünü kapsadığı için ayrıca buraya Mendoza et al. (1994)'nin yaptığı gibi sosyal güvenlik primleri işveren hissesini eklemeye gerek kalmamıştır.

2 Türkiye'de ücret gelirleri ă̆ırlıklı olarak kaynakta tevkif yoluyla vergilendirilmektedir. Dolaylslyla ücretler üzerinden alınan gelir vergisi içinde ylllk gelir vergisi beyannamesi verilmek suretiyle tahsil edilen gelir vergisinin ihmal edilebilir düzeyde olduğunu varsayıyoruz.

3 Burada ücret ve maaş bordroları üzerinden tevkif edilen damga vergisi hesaplamaya dahil edilmemiștir. 


\subsubsection{Sermaye Üzerindeki Efektif Vergi Yükü}

Sermaye üzerindeki efektif vergi yükünü hesaplamak için iki farklı vergi türünü dikkate almak gerekir. Bunlardan ilki gelir üzerinden alınan vergilerdir. Örneğin bireysel kazançlardan alınan gelir vergisi ile kurumsal kazançlardan alınan kurumlar vergisi ilk gruba girmektedir. İkincisi ise hane halkları ve kurumların taşınır veya taşınmaz varlıkları üzerindeki servet vergileridir. Bu çalışmada sermaye üzerindeki efektif vergi yükünü hesaplamak için her iki vergi grubu da dikkate alınmaktadır. Ancak kişisel kazançlar üzerinden alınan gelir vergisinin bir bölümü ücret ve maaş gelirleri üzerinden ödenmektedir. Yukarıda da açıklandığı gibi emek gelirlerinden ödenen gelir vergisi payının toplam gelir vergisi tutarından düşülmesi gerekir. Dolayısıyla burada (1100) koduyla ifade edilen gelir vergisi toplamından yukarıda ücretliler tarafından ödendiği ifade edilen (1113a) kodlamasıyla görülen tutarın düşülmesi gerekir. Böylece sadece ücretli olmayanların ödediği kişisel gelir vergisi tutarı elde edilmiş olur.

Ayrıca aşağıdaki formül (6)'nın payına veri setinde (1120) koduyla ifade edilen kurumlar vergisinin eklenmesi gerekir. Veri setinde (1200) sinıflandirma koduyla ifade edilen mülkiyet üzerinden alınan vergiler (veraset ve intikal vergisi, motorlu taşıtlar vergisi, bina vergisi, arsa vergisi, arazi vergisi, vb.) ile (1900) sinıflandırma koduyla ifade edilen vergilerin formülün payına eklenmesi gerekir. Ayrıca veri setimizde (2000b) sınıflandırma koduyla ifade edilen bağımsız çalışanların kendileri adına ödedikleri primler de sermaye üzerinden ödenen vergiler olarak dikkate alınmıştır. Aşağıdaki formül (6)'nın paydasında ise net işletme artığ artığından sabit sermaye tüketimi tutarı düşüldükten sonra kalan miktardır. Bu tutar yaklaşık olarak kâr, faiz ve kira gelirleri toplamına karşlık gelmektedir.

$$
\tau \text { Sermaye }=\left[\frac{((1100-1113 a)+1120+1200+1900+2000 b)}{\text { Net OS }}\right] \times 100
$$

Yukarıda sermaye üzerindeki efektif vergi yükünü ölçmek için kullandığımız formül (6) Mendoza et al. (1994)'nin geliştirdikleri formül (4)'ten sadece iki noktada ayrılmaktadır. Birincisi formül (6)'nın payında yer alan (1100) sınıflandırma koduyla ifade edilen gelir üzerinden alınan vergilerden ücret ve maaş gelirleri üzerinden ödenen (1113a) kodlu gelir vergisi düşülmüsstür. Oysa Mendoza et al. (1994) bu hesaplama için hane halkının ortalama vergi oranını gösteren (formül 2)'yi kullanmışlardır.

Öte yandan sermaye üzerindeki vergi yükünün ölçülmesinde paydada yer alan kavramsal vergi matrahı da Mendoza et al. (1994) tarafindan kullanılan kavramsal vergi matrahından farklıdır. Zira Mendoza et al. (1994) sermaye üzerindeki efektif vergi yükünü ölçmek için işletme artı̆̆ını olduğu gibi paydaya yazmışlardır. Bu, sermaye üzerindeki vergi yükünün olduğundan düşük hesaplanması anlamına gelir. Zira vergi sistemleri genel olarak amortisman giderlerinin kazançlardan indirilmesine izin verir. Dolayısıyla burada net işletme artığının kavramsal vergi matrahı olarak kullanılması kanımızca daha gerçekçi bir ölçüm yapmaya imkân tanımaktadır. 
$\mathrm{Bu}$ haliyle sermaye üzerindeki efektif vergi yükünü ölçmek için oluşturduğumuz formül (6) Carrey \& Rabesona (2004:217) tarafından uygulanan metodolojiden de farklılaşmaktadır. Zira Carrey \& Rabesona (2004) sermaye üzerindeki efektif vergi yükünün ölçülmesinde MRT metodolojisiyle oldukça yakınlaşmaktadır. Öyle ki neredeyse tek fark, sermaye üzerinden alınan vergilerin kavramsal matrahını oluşturan işletme artığından (OS) sadece bordo vergisi ile işgücü üzerinden ödenen vergilerin düşülmesidir. Oysa her ülkede uygulanmayan söz konusu vergilerin işletme artığından (OS) düşülmesi yerine kavramsal vergi matrahı olarak net işletme artığının (net OS) alınması daha uygun bir yaklaşım olacaktır.

\subsubsection{Harcamalar Üzerindeki Efektif Vergi Yükü}

Harcamalar üzerindeki efektif vergi yükünün ölçülmesinde MRT metodolojisinden farklı iki yol izlenmektedir. İlki hesaplamaya dolaylı vergilerin tümünün dahil edilmesi ve bu vergilerin paydadaki harcama tutarlarından düşülmesi şeklinde yapılmaktadır. Burada kavramsal vergi matrahı vergi tutarları kadar küçültülmüş olmaktadır. İkincisi ise paydaki dolaylı vergi sayısını artırmakla birlikte paydadaki harcama tutarlarından söz konusu vergileri düşmeden vergi yükünün hesaplanması şeklinde uygulanmaktadır. Bu ikinci yöntem Carrey \& Rabesona (2004: 217) tarafından uygulanmıştır. Ancak bu yöntem MRT metodolojisine göre daha fazla sayıda dolaylı vergiyi hesaplamaya dahil etmesi bakımından gerçekçi iken, söz konusu dolaylı vergilerin kavramsal vergi matrahı olan tüketim harcamaları toplamından düşülmemesi hesaplamanın gerçekçi olmasına engel teşkil etmektedir. Zira Türkiye'de olduğu gibi birçok ülkede dolaylı vergiler tüketim harcamalarına dahil edilmektedir. Bu nedenle aşağıda daha geniş bir dolaylı vergi kategorisi dikkate alınarak MRT metodolojisine daha yakın bir hesaplama biçimi tercih edilmektedir.

$\mathrm{Bu}$ amaçla veri setinde (1300) sınıflandırma kodu altında toplanmış olan dahilde alınan mal ve hizmet vergileri, (1400) sınıflandırma kodu altında toplanmış olan uluslararası ticaret ve muamelelerden alınan vergileri, (1500) sınıflandırma koduyla ifade edilen damga vergisi ve (1600) sınıflandırma koduyla ifade edilen harçlar hesaplamaya dahil edilmiştir. Aşağıdaki formül (7)'nin payında yer alan söz konusu vergiler harcamalar ve muameleler üzerinden alınan vergilerin tamamını kapsamaktadır.

$$
\tau T \ddot{u} k e t i m=\left[\frac{(1300+1400+1500+1600)}{C+G C-G W-(1300+1400+1500+1600)}\right] \times 100
$$

Formül (7)'nin paydasında ise hane halklarının ve hane halklarına karşılıksız yardım eden kâr amacı gütmeyen kurumların nihai tüketim harcamaları bulunmaktadır. Ayrıca paydaya devletin kamu çalışanları için ödediği maaş ve ücretleri düştükten sonra kalan devletin nihai tüketim harcamaları eklenmiştir. Ancak dolaylı vergilerin dahil olmadığı net vergi matrahına ulaşabilmek için formül (7)'nin payına yazılmış olan vergilerin paydadaki harcamalar toplamından düşülmesi gerekmektedir. 


\section{Ampirik Bulgular}

Bu çalışmada ulaşılan bulgular Tablo 4 ve Şekiller (1-2-3) aracılığıyla sunulmaktadır. Tablo 4 Türkiye'de 2006-2019 yılları arası dönemde emek, sermaye ve tüketim üzerindeki efektif vergi yüklerini göstermektedir. Ölçüm sonuçları Türkiye'de emek üzerindeki efektif vergi yükününün sermaye ve tüketim üzerindeki efektif vergi yüküne göre daha yüksek olduğunu göstermektedir. Tüketim üzerindeki efektif vergi yükünün emek üzerindeki efektif vergi yüküne göre daha düşük olduğu, ancak tüketim üzerinde de önemli miktarda efektif vergi yükü olduğu görülmektedir. Sermaye üzerindeki efektif vergi yükü ise diğgerlerine göre oldukça düşük düzeyde çıkmıştır. Öte yandan bulgular emek üzerindeki efektif vergi yükünün incelediğimiz dönemde en düşük değere 2006 yılında $(\% 26,27)$, en yüksek değere ise 2013 yılında $(\% 31,69)$ ulaştığını göstermektedir. Sermaye üzerindeki efektif vergi yükünün ise aynı dönemde en düşük değere 2013 yılında $(\% 8,59)$, buna karşılık en yüksek değere ise 2018 yılında $(\% 10,92)$ ulaştı̆̆ efektif vergi yükünün 2006-2019 yılları arasında en düşük değere 2019 yılında $(\% 17,40)$, en yüksek değere ise 2013 yılında $(\% 22,19)$ ulaştı̆̆ı görülmektedir.

\section{Tablo: 4}

Türkiye'de Emek, Sermaye ve Tüketim Üzerindeki Efektif Vergi Yükü (\%) (2006-2019)

\begin{tabular}{|c|c|c|c|}
\hline Y1llar & $\begin{array}{c}\text { Emek Üzerindeki } \\
\text { Efektif Vergi Yükü (\%) }\end{array}$ & $\begin{array}{c}\text { Sermaye Üzerindeki } \\
\text { Efektif Vergi Yükü (\%) }\end{array}$ & $\begin{array}{c}\text { Tüketim Üzerindeki } \\
\text { Efektif Vergi Yükü (\%) }\end{array}$ \\
\hline 2006 & 26,27 & 9,84 & 21,13 \\
\hline 2007 & 26,58 & 9,50 & 19,93 \\
\hline 2008 & 27,20 & 10,40 & 19,17 \\
\hline 2009 & 28,08 & 10,23 & 21,32 \\
\hline 2010 & 28,46 & 9,70 & 21,54 \\
\hline 2011 & 30,20 & 10,52 & 20,79 \\
\hline 2012 & 30,38 & 9,75 & 22,19 \\
\hline 2013 & 31,69 & 8,59 & 20,84 \\
\hline 2014 & 30,36 & 9,09 & 21,68 \\
\hline 2015 & 30,67 & 9,18 & 21,43 \\
\hline 2016 & 28,36 & 10,11 & 21,05 \\
\hline 2017 & 29,72 & 9,50 & 19,34 \\
\hline 2018 & 29,12 & 10,92 & 17,40 \\
\hline 2019 & 28,96 & 10,40 & $\mathbf{2 0 , 4 7}$ \\
\hline Ort. & $\mathbf{2 9 , 0 0}$ & $\mathbf{9 , 8 4}$ & \\
\hline
\end{tabular}

Kaynak: Yazarlar tarafindan hesaplanmıştır.

Tablo 4'teki verilerden hareketle oluşturulan Şekil 1 ise emek, sermaye ve tüketim üzerindeki efektif vergi yükünün seyrini daha kolay izlemeye imkân sağlamaktadır. Şekil 2'de emek üzerindeki efektif vergi yükünün 2006-2013 arasında artış gösterdiği, ancak 2014-2019 yılları arasında ise daha dalgalı bir seyir izlediği görülmektedir. Tüketim üzerindeki efektif vergi yükünün emek ve sermaye üzerindeki vergi yüküne göre incelenen dönemde daha fazla dalgalanma gösterdiği anlaşılmaktadır. Tüketim üzerindeki efektif vergi yükünün 2006-2009 yılları arasında azalış yönünde seyrettiği, ancak 2010-2015 yılları arasında daha küçük dalgalanmalar göstererek genel olarak artış yönünde bir seyir izlediği görülmektedir. 2016 yılından sonra hafif gerileme seyrine giren tüketim üzerindeki efektif vergi yükünün 2017-2019 yılları arasında bariz biçimde gerilediği anlaşılmaktadır. 
Şekil: 1

Türkiye'de Emek, Sermaye ve Tüketim Üzerindeki Efektif Vergi Yükü (\%) (2006-2019)

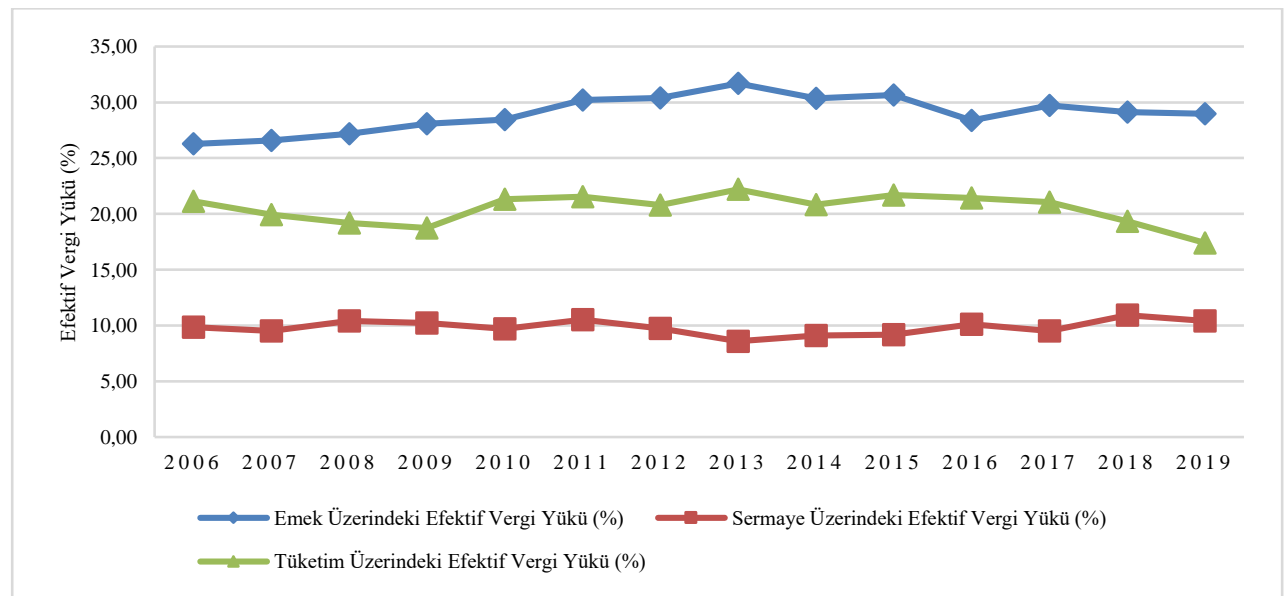

Kaynak: Tablo 4 'te sunulan verilere dayanmaktadır.

Sermaye üzerindeki efektif vergi yükü ise 2006-2019 yılları arasında daha istikrarlı bir seyir izlemiş durumdadır. Ancak 2013 yılında emek ve tüketim üzerindeki efektif vergi yükü dönemin en yüksek seviyelerine ulaşırken, sermaye üzerindeki efektif vergi yükünün düşmüş olması dikkat çekicidir. Aynı ters yönlü ilişki bu sefer 2018-2019 yılları arasında tüketim üzerindeki efektif vergi yükü ile sermaye üzerindeki efektif vergi yükü arasında gözlemlenmektedir. Söz konusu dönemde tüketim üzerindeki efektif vergi yükü düşerken, sermaye üzerindeki efektif vergi yükü artış yönünde bir seyir izlemektedir.

Şekil 2 ekonominin performansıyla ile efektif vergi yüklerinin seyri arasındaki ilişkiyi göstermektedir. Burada ekonomik daralma ve genişlemeye en duyarlı verginin tüketim üzerinden alınan vergiler olduğu sonucu ortaya çıkmaktadır. Şekil 2 üzerinde görüldügü gibi 2008-2009 ekonomik krizi sırasında ve daha sonra 2017-2019 arasında yaşanan ekonomik daralma (büyüme oranlarının düşmesi) tüketim üzerindeki efektif vergi yükünün de düşmesiyle sonuçlanmış görünmektedir. Oysa aynı ilişki 2006-2007 arasında ve ardından 2010-2016 yılları arasında ters yönde gelişmiştir. Zira ekonomik büyüme oranları pozitif yönde seyrederken tüketim üzerindeki efektif vergi yükü artış yönünde ivme kazanmıştır. Benzer bir gelişme emek üzerindeki efektif vergi yükü için gözlemlenmektedir. Özellikle 2010-2013 yıllarında ekonomi genişlerken emek üzerindeki efektif vergi yükü de artış yönünde bir eğilim içinde olmuştur. Öte yandan Şekil 2'deki sermaye üzerindeki efektif vergi yükünün seyrine bakıldığında, sermaye üzerinden alınan vergilerin ekonomik genişleme veya daralmaya daha az duyarlı olduğu görülmektedir. 
Şekil: 2

Efektif Vergi Yükleri ve Büyüme Oranlarının Seyri (2006-2019)

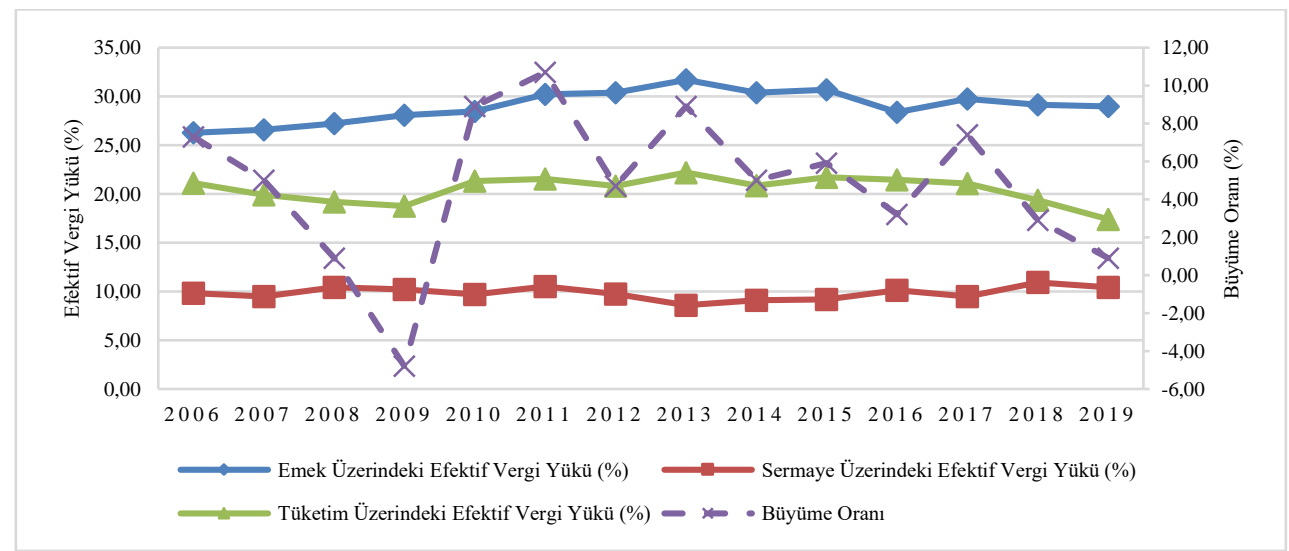

Kaynak: Büyüme oranları TÜIKK (2020c)'den alınmıştır.

Ekonominin içinde bulunduğu durumu kavramaya imkân sağlayan makroekonomik göstergelerden biri de işsizlik oranlarıdır. Şekil 3'te 2006-2019 yılları arasında işsizlik oranları ile efektif vergi yükleri arasındaki ilişki gösterilmektedir. Burada emek üzerinden alınan vergilerin işsizlik oranlarındaki dalgalanmaya daha duyarlı olduğu görülmektedir. Zira işsizlik oranlarının düşme eğilimi gösterdiği 2010-2013 yılları arasında emek üzerindeki vergi yükünün arttığı gözlemlenmektedir. Oysa işsizlik oranlarının yeniden artış yönünde ivme kazandığı 2014-2019 yılları arasında ise emek üzerindeki vergi yükünün küçülme yönünde bir seyir izlediği ortaya çıkmaktadır.

Şekil: 3

Efektif Vergi Yükleri ve İşsizlik Oranlarının Seyri (2006-2019)

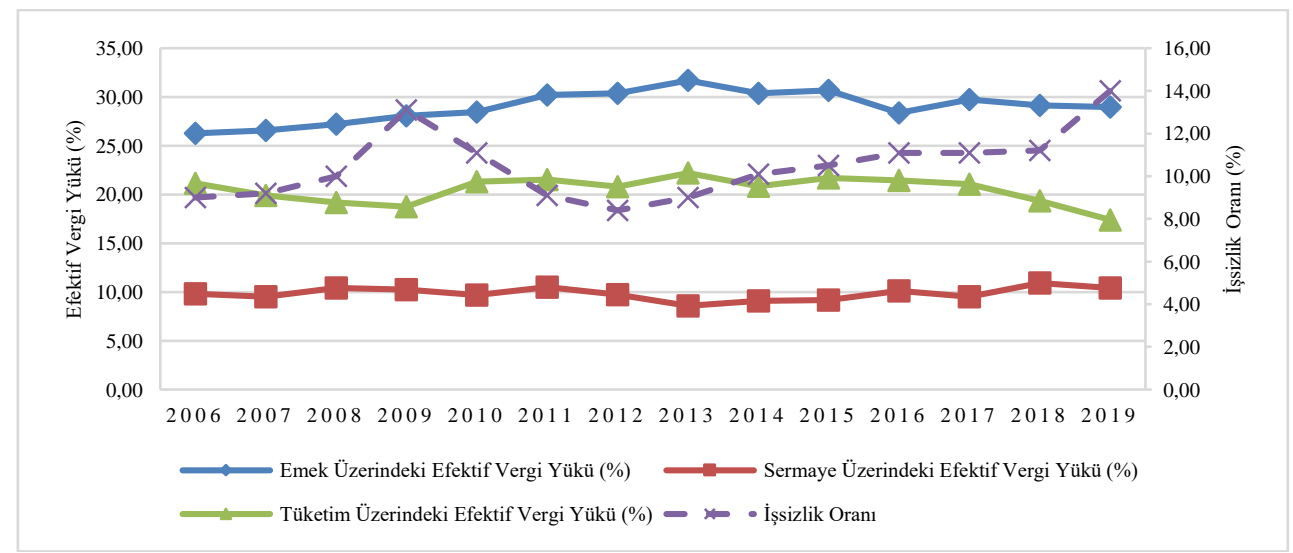

Kaynak: İssizlik oranları TÜIKK (2020d)'den alınmıştır. 
Ekonominin daraldığı ve işsizlik oranlarının arttığ dönemlerde tüketim üzerindeki efektif vergi yükünün düştüğü tersine ekonominin genişleme dönemlerinde ise tüketim üzerindeki efektif vergi yükünün artış yönünde seyrettiği görülmektedir. Örneğin 2010-2014 yılları arası işsizlik oranı düşerken tüketim üzerindeki efektif vergi yükü artış yönünde bir seyir izlemiş durumdadır. Ancak 2008-2009 yılları ile 2015-2019 yılları arasında ise işsizlik oranları artarken tüketim üzerindeki vergi yükünün düşme eğilimine girdiği gözlemlenmektedir. Sermaye üzerindeki efektif vergi yükünün ise ekonominin içinde bulunduğu konjonktürden fazla etkilenmemiş olduğu görünmektedir. İşsizlik oranındaki dalgalanmalara rağmen Şekil 3 'te sermaye üzerindeki efektif vergi yükünün yatay bir seyir izlediği anlaşılmaktadır.

\section{Bulguların Tartışılması}

Bulguların tartışmasına emek üzerindeki efektif vergi yükü sonuçlarını değerlendirerek başlıyoruz. Daha sonra sırasıyla sermaye ve tüketim üzerindeki efektif vergi yükü ele alınacaktır. Türkiye'de 2006-2019 döneminde emek üzerindeki efektif vergi yükünün sermaye ve tüketim üzerindeki efektif vergi yüküne göre oldukça yüksek olduğu sonucu ortaya çıkmıştır. Daha önce belirtildiği gibi emek üzerindeki efektif vergi yükünün 2006 yılından 2013 yılına kadar artış yönünde 2014 yıldan 2019 yılına doğru ise azalış yönünde bir eğilim gösterdiği görülmektedir. Bununla birlikte emek üzerindeki 14 yıllık ortalama efektif vergi yükü \%29,00’dır (Bkz. Tablo 4 son satır). Ortaya çıkan bu sonucun genel olarak Türk vergi sisteminin yapısından kaynaklandığı düşüncesindeyiz. Gelir vergisi hasılatının 2006-2019 yılları arasında yaklaşık \%58,14'ü ücret ve maaş gelirlerinden kesinti yoluyla tahsil edilen gelirlerden oluşmaktadır ${ }^{4}$.

Emek üzerindeki efektif vergi yüküne etki eden bir diğer vergi ise sosyal güvenlik primleridir. Sosyal güvenlik primleri işçi ve memurların maaş ve ücretleri üzerinden işveren tarafından kaynakta kesinti yoluyla ödenmektedir. Sosyal güvenlik prim oranları iş kollarına göre değişmekle birlikte çalışan ve işveren hissesi toplamı \%20 civarındadır. Dolayısıyla sosyal güvenlik primleri emek üzerindeki vergi yükünün artmasına katkı sağlayan önemli vergisel faktörlerden biridir. Ayrıca 2000 yılından itibaren uygulana gelen işsizlik sigortası fonu primleri ise işçi ve işveren payı (devlet katkısı hariç) toplamı \%3 olarak ücretlere yansıyan bir yükümlülüktür. Öte yandan incelediğimiz dönemde gerek 193 sayılı Gelir Vergisi Kanunu'nda gerekse 5510 sayılı Sosyal Sigortalar ve Genel Sağlık Sigortası Kanunu'nda ve gerekse de 4447 sayılı İşsizlik Sigortası Fonu Kanunu'nda emek üzerindeki vergi yükünü artırıcı veya azaltıcı yönde sonuç doğuran çok önemli değişiklikler yapılmamıştır. Buna rağmen emek üzerindeki efektif vergi yükünde gözlemlenen dalgalanmanın daha ziyade ekonomide yaşanan gelişmelerden kaynaklandığı anlaşılmaktadır.

Gelir İdaresi Başkanlı̆̆ının Yıllık Faaliyet Raporlarında sunulan ücret gelirlerinden kaynakta kesinti yoluyla tahsil edilen gelir vergisinin toplam gelir vergisi hasılatına oranlarının (2006-2019 arasi) 14 yıllı ortalaması. 
Zira işsizlik oranlarının azaldığı ve ekonomik büyüme oranlarının yüksek seyrettiği 2010-2013 yıllarında emek üzerindeki efektif vergi yükü artmıştır. Bu artışa aynı zamanda gayri safi yurtiçi hasıla içinde işgücü ödemelerinin payında görülen artış da eşlik etmiştir. Bunun tersine ekonomide daralmanın yaşandığı 2014-2019 arası dönemde ise emek üzerindeki efektif vergi yükünün aşağı yönlü bir seyir izlemeye başladığı görülmektedir. İncelenen dönemde ekonomik konjonktürle emek üzerindeki vergi yükünün etkileşim içinde olmadığını gösteren tek örnek 2008-2009 ekonomik krizi döneminde gerçekleşmiş görünmektedir. Zira bu dönemde ekonomik büyüme oranları negatif yönde seyrederken ve işsizlik oranları artmışken, emek üzerindeki efektif vergi yükü az da olsa artış yönünde seyretmiş durumdadır. Bu sonucun ekonomik sebeplerden ziyade dönemin tek parti iktidarının getirdiği siyasi istikrar nedeniyle toplumda ekonomik krizin kısa süreli olacağı beklentisinin güç kazanmış olmasından kaynaklandığını düşünüyoruz.

Sermaye üzerindeki efektif vergi yükü ise 2006-2019 yılları arasında daha istikrarlı bir seyir izlemiştir. Sermaye üzerindeki efektif vergi yükünün 14 yıllık ortalaması \%9,84'tür (Bkz. Tablo 4). Sermaye üzerindeki efektif vergi yükü emek ve tüketim üzerindeki efektif vergi yüküne göre oldukça düşük çıkmıştır. Bu sonucun sermaye kazançları ile servet ve taşınmazlara uygulanan vergi kanunlarıyla ilgili düzenlemelerden kaynaklandığını düşünüyoruz. Zira kavramsal vergi matrahı olarak kullandığımız net işletme artığı (Net OS) incelediğimiz dönemde artış eğilimini sürdürmüştür. Önce sermaye üzerindeki vergi yükünü artırıcı yönde yapılan düzenlemelere ilişkin birkaç hususa değinelim. Bunlardan ilki kurumlar vergisi oranının 2018, 2019 ve 2020 yılıyla sinırlı olarak \%20'den \%22'ye çıkarılmış olmasıdır. İkincisi ise kayıt dışı ekonomiyle ilgili olarak alınan tedbirlerdir. Bu alanda çok fazla önlem alınmıştır ${ }^{5}$. Ancak yine de sermaye üzerinden alınan vergilerin genellikle mükellef tarafından beyan ediliyor olması önemli miktarda kazanç veya iradın beyan dışı bırakılmasına imkân sağlamaktadır.

Öte yandan vergi kanunlarında sermaye üzerindeki vergi yükünü azaltıcı yönde yapılan düzenlemelerin daha fazla olduğu görülmektedir. Örneğin indirimli kurumlar vergisi oranı uygulaması teşvik belgesi almış kurumların vergi yükünde önemli azalmalara sebep olmuştur. Bunun yanı sıra incelenen dönemde gelir ve kurumlar vergisi kanununda mükelleflere vergi avantajı sağlayan çok sayıda düzenleme yapılmıştır. Özellikle vergi istisna ve muafiyetleri ile vergi indirimlerini düzenleyen maddelerde bunu görmek mümkündür. Örneğin menkul sermaye iratları ile ilgili olarak gelir vergisi kanunun geçici 67. maddesindeki düzenlemeler sermaye üzerindeki vergi yükünü azaltıcı yöndedir. Ayrıca incelediğimiz dönemde gerçek usulde vergilendirilen gelir ve kurumlar vergisi mükelleflerine avantajlar sağlayan çok sayıda vergi af kanunu yürürlüğe konulmuştur 6 .

5 Bu kapsamda nakit ödemelere getirilen kısıtlama, elektronik fatura düzenleme zorunluğu, BA ve BS formlarl, hazır beyanname uygulaması, pos cihazı kullanımınin yaygınlaştırlmast, muhtasar beyanname ile sosyal güvenlik bildiriminin birleştirilmesi, $v$ b. birçok uygulama sayılabilir.

6 2006-2019 döneminde 7 adet vergi a kanununun yürürlüğe konulduğu görülmektedir. Bunlar 22/11/2008 tarihli 5811 sayll Kanun; 25/02/2011 tarihli 6111 sayll Kanun; 29/05/2013 tarihli 6486 sayll Kanun; 10/09/2014 tarihli 6552 sayll Kanun; 19/08/2016 tarihli 6736 sayll Kanun; 27/05/2017 tarihli 7020 sayll Kanun ile 18/05/2018 tarihli 7143 sayılı Kanunlardan oluşmaktadır. 
Ayrıca vergi uzlaşma uygulamaları, vergi denetiminin yetersizliği, vergi cezalarının caydırıcı olmaması gibi faktörler de sermaye üzerindeki vergi yükünün düşük kalmasına katkı sağlayan unsurlardır. Öte yandan sermaye üzerinden alınan veraset ve intikal vergisi, emlak vergisi, çevre temizlik vergisi gibi vergiler yeterince vergi hasılatı sağlamaktan uzak, etkin olmayan vergilerdir.

Bu bölümde son olarak tüketim üzerindeki efektif vergi yükü değerlendirilecektir. Tüketim üzerindeki efektif vergi yükünün 2006-2019 yılları arası 14 yı1lık ortalaması $\% 20,47$ olmuştur (Bkz. Tablo 4). Ancak tüketim üzerindeki efektif vergi yükünün diğer iki ekonomik faktör üzerindeki efektif vergi yüküne göre oldukça fazla dalgalandığ görülmektedir. $\mathrm{Bu}$ dalgalanmanın vergi mevzuatından ziyade ekonominin daralma ve genişleme dönemlerine göre hane halklarının nihai tüketim harcamalarından kaynaklandığını düşünüyoruz. Zira tüketim üzerinden alınan vergilere ilişkin mevzuatta vergi yükünü azaltıcı yönde çok az sayıda düzenleme yapılmıştır. Örneğin 2008 ekonomik krizi sırasında seçilmiş bazı ürünler üzerindeki katma değer vergisi ve özel tüketim vergisi geçici bir süre için indirilmiştir ${ }^{7}$. Keza tekstil ürünleri başta olmak üzere eğitim ve sağlık hizmetlerinde \%18 olarak uygulanan katma değer vergisinin \%8'e indirildiği bir gerçektir. Bununla birlikte özel tüketim vergisinde farklı kalemlerdeki mal teslimleri için çok sayıda vergi oranı artışı yapılmıştır. Ayrıca yukarıda sermaye üzerinden alınan vergileri değerlendirirken belirtildiği gibi vergi affı uygulamaları da tüketim üzerinden alınan vergilerin dalgalanmasına katkı sağlamıştır.

Ancak görebildiğimiz kadarıyla tüketim üzerindeki efektif vergi yükünün ekonomide yaşanan çevrimlere daha duyarlı olduğu anlaşılmaktadır. Zira daha önce bulguların sunulduğu bölümde belirtildiği gibi büyüme oranlarının düştüğü ve işsizlik oranlarının arttığı, yani ekonominin daraldığı dönemlerde tüketim üzerindeki efektif vergi yükü düşmüştür. Örneğin 2008-2009 yıllarında yaşanan ekonomik kriz dönemi ile 2017-2019 yılları arasında yaşanan ekonomik daralma döneminde tüketim üzerindeki efektif vergi yükünün düştüğü görülmektedir (Bkz. Şekil 2 ve Şekil 3). Öte yandan bu sonucu doğal karşılamak gerekir zira tüketiciler ekonomik kriz veya durgunluk dönemlerinde daha az harcama yapma yönünde davranışlar sergileyebilmektedir. Bununla birlikte ekonominin genişlediği dönemlerde ise tüketim üzerindeki efektif vergi yükü artış göstermektedir. Bu durum 2010-2016 yılları arasında açıkça görülmektedir (Bkz. Şekil 2 ve Şekil 3).

\section{Sonuç}

$\mathrm{Bu}$ çalışmada ulaşılan bulgular, Türkiye'de sermaye üzerindeki efektif vergi yükünün, tüketim ve emek üzerindeki efektif vergi yüküne göre oldukça düşük olduğunu göstermektedir. Sermaye üzerindeki efektif vergi yükünün düşük olmasının yatırım ve tasarrufların düşük vergilendirilmesi açısından olumlu bir gelişme olduğunun vurgulanması gerekir. Hatta sermaye üzerindeki efektif vergi yükü ölçüm yaptığımız dönem içinde

2008-2009 ekonomik krizi sırasında geçici olarak alınan vergisel tedbirlerin özetlendiği bir çalışma için bkz. Elele (2009). 
Nacar, B. \& Y. Karabacak (2022), “Türkiye'de Emek, Sermaye ve Tüketim

Üzerindeki Efektif Vergi Yükü: 2006-2019”, Sosyoekonomi, 30(51), 487-510.

oldukça istikrarlı sayılabilecek bir seyir izlemiştir. Bu olumlu yönüne rağmen sermaye üzerindeki vergi yükünün düşük tutulması toplumda vergi yükünün adil dağılımı bakımından kendi içinde bir olumsuzluk da barındırmaktadır. Öyle ki sermaye üzerindeki efektif vergi yükü, 2006-2019 yılları arasında ortalama \%9,84 düzeyindeyken; tüketim üzerindeki efektif vergi yükü ortalama \%20,47 düzeyinde olmuş; emek üzerindeki efektif vergi yükü ise ortalama \%29,00 olarak geçekleşmiştir. Böylesi bir vergi yükü dağılımının toplumda vergilemeye ilişkin adalet algısını olumsuz yönde etkileyerek uzun dönemde vergiye gönüllü uyumu azaltma riski taşıdığını belirtmek gerekir. Dolayısıyla ekonomide gönüllü tasarrufların önemini göz ardı etmeden zorunlu bir tasarruf arac1 olarak vergilemenin sağlayacağı kamu yararını da düşünerek sermaye üzerinden alınan vergilerde düzenlemelerin yapılması gerektiği kanaatindeyiz.

Öte yandan bu çalışmada ulaşılan bulgular, emek üzerindeki efektif vergi yükünün sermaye ve tüketim üzerindeki efektif vergi yüküne göre oldukça yüksek olduğunu göstermektedir. Hatta emek üzerindeki efektif vergi yükünün, ölçüm yapılan dönem içinde meydana gelen ekonomik kriz veya durgunluk zamanları hariç, genel bir artış eğilimi içinde olduğu gözlemlenmektedir. Bunun temelde tercih edilen vergileme politikaları nedeniyle iki sebebi olduğunu düşünüyoruz. Birincisi küreselleşme ve sermaye hareketlerinin serbest dolaşımının önündeki engellerin kaldırılmasıyla birlikte devletler ister istemez emek gibi mobilite kapasitesi düşük vergi konularına odaklanmak zorunda kalmışlardır. İkincisi ise sosyal devlet anlayışındaki değişim sosyal harcamaların finansman yükünü ister istemez faydalananlara ödetme yönünde gelişmelere neden olmuştur. Bütün bunların neticesi olarak, Türkiye'de emek gelirleri üzerindeki efektif vergi yükünün arttığ́1 görülmektedir. Ancak böyle bir gelişmenin istihdamı olumsuz yönde etkilemesi muhtemeldir. Zira emek maliyetlerinin istihdam üzerindeki vergiler nedeniyle sürekli yükselmesi her şeyden önce emek talebini olumsuz yönde etkileyecektir. Aynı şekilde emek gelirleri üzerindeki vergi yükünün ağırlığı çalışma arzusunu olumsuz yönde etkileyerek emek arzının kısılmasıyla sonuçlanabilecektir.

Son olarak tüketim üzerindeki efektif vergi yükünün sermaye üzerindeki efektif vergi yükünden daha yüksek olması (neredeyse bir kat fazla) yatırım ve tasarruf yerine tüketimin vergilendirmesi bakımından olumlu bir gelişme olarak değerlendirilmelidir. Zira tüketimin vergilerle baskılanması bir yerde kaynakların gönüllü tasarruf veya yatırıma kanalize olmasına olanak tanıyabilir. Ancak aynı zamanda tüketim üzerindeki efektif vergi yükünün yüksekliği tüketim vergilerinin tipik özellikleri nedeniyle vergi adaletini olumsuz yönde etkileyebilir. Zira katma değer vergisi veya özel tüketim vergisi gibi harcama vergileri düşük gelirli toplumsal kesimler üzerinde tersine artan oranlı etkiler yaratarak vergi yükünün adil dağılımı engelleyebilir. Ayrıca tüketim üzerindeki efektif vergi yükünün ekonominin içinde bulunduğu konjonktürden çok fazla etkilendiği görülmektedir. İnsanların ekonominin daralma döneminde tüketim harcamalarını kısarak daha tedbirli davrandıkları bir gerçektir. Hal böyle olunca tam da kriz dönemlerinde daha fazla gelir gereksinimi içinde olan devletin neredeyse otomatik olarak tüketim vergilerinde bir kayıpla ile karşı karşıya kalması muhtemeldir. Dolayısıyla vergi yapısı içinde tüketim üzerinden alınan vergilere fazla ağırlık vermek zaman zaman devletlerin gelir istikrarsızlığı ile karşılaşma olasılığını artırmaktadır. 


\section{Kaynaklar}

Bellak, C. \& M. Leibrecht (2007), "Corporate Income Tax Competition and the Scope for National Tax Policy in the Enlarged Europe", in: K. Andersson et al. (eds.) National Tax Policy in Europe: To be or Not to Be? (11-43), Berlin, Heidelberg: Springer.

Carey, D. \& H. Tchilinguirian (2000), "Average Effective Tax rates on Capital, Labour and Consumption”, Economics Department Working Papers, 258, Paris: OECD Economic Department.

Carey, D. \& J. Rabesona (2004), “Tax Rations on Labor and Capital Income and on Consumption”, in: P.B. Sørensen (ed.), Measuring Taxes on Capital and Labor (213-262), CESifo Seminar Series, London: The MIT Press.

Clark, W.S. (2004), "Using Micro-Data to Assess Average Tax Rates”, in: P.B. Sørensen (ed.), Measuring Taxes on Capital and Labor (319-358), CESifo Seminar Series, London: The MIT Press.

Devereux, M.P. \& R. Griffith (1999), "The taxation of discrete investment choices", IFS Working Paper Series No. W98/16.

Elele, O. (2009) “Küresel krize karşı Türkiye'de alınan önlemler”, Dünya Gazetesi (29 Ağustos 2009), < https://www.dunya.com/gundem/gs039nin-avrupa039daki-rakipleripanathinaikos-d-bukres-ve-s-haberi-88224 > 26.10.2021.

European Commission (2020), Taxation Trends in the European Union Data For The EU Member States, Iceland and Norway, (2020 Edition), Directorete-General for Taxation and Customs Union, European Commission, Publications Office of the European Union, Luxembourg.

Gelir İdaresi Başkanlığı (2007), 2006-2020 Yllı Faaliyet Raporlarl, <https://www.gib.gov.tr>, 10.12.2020.

Gordon, R. et al. (2003), “Do we now collect any tax revenue from taxing capital income?”, Journal of Public Economics, 88, 981-1009.

Hazine ve Maliye Bakanlığı (2020a), Genel Yönetim Bütçe Gelirleri Ekod4 2019, <https://muhasebat.hmb.gov.tr/genel-yonetim-butce-istatistikleri>, 15.12.2020.

Hazine ve Maliye Bakanlığı (2020b), Genel Yönetim Bütçe Gelirleri Ekod4 2011-2018, <https://muhasebat.hmb.gov.tr/genel-yonetim-butce-istatistikleri>, 15.12.2020.

Hazine ve Maliye Bakanlığı (2020c), Merkezi Yönetim Bütçe Gelirleri Ekod4 2006-2010, <https://muhasebat.hmb.gov.tr/genel-yonetim-butce-istatistikleri>, 15.12.2020.

Hazine ve Maliye Bakanlığ (2020d), Mahalli İdareler Bütçe Gelirleri Ekod4 2006-2010, <https://muhasebat.hmb.gov.tr/mahalli-idareler-butce-istatistikleri>, 15.12.2020.

Jacobs, O.H. \& C. Spengel (1999), "The Effective Average Tax Burden in the European Union and the USA A Computer-based Calculation and Comparison with the Model of the European Tax Analyzer", ZEW Discussion Papers, No. 99-54, Zentrum für Europäische Wirtschaftsforschung (ZEW), Mannheim.

Jacobs, O.H. \& C. Spengel (2002), "Effective Tax Burden in Europe”, ZEW Economic Studies, 15, Heidelberg/ New York.

King, M.A. \& D. Fullerton (1984), The Taxation of Income From Capital: A Comparative Study of the United States, United Kingdom, Sweden, and West Germany, Chicago: University of Chicago Press. 
Kostarakos, I. \& P. Varthalitis (2020), "Effective tax rates in Ireland", The Economic and Social Research Institute Research Series Number 110.

Leibrecht, M. \& R. Römisch (2002), “Comparison of Tax Burdens”, wiiw Research Report, No. 292, The Vienna Institute for International Economic Studies (wiiw), Vienna.

Martinez-Mongay, C. (2000), ECFIN's Effective tax rates. Properties and Comparisons with other tax indicators, <ttps://www.researchgate.net/publication/46447658_ECFIN\%27s_effective_tax_ratesPro perties_and_comparisons_with_other_tax_indicators>, 27.10.2021.

Mendoza, E.G. et al. (1994), "Effective Tax Rates in Macroeconomics Cross-country Estimates of Tax Rates on Factor Incomes and Consumption", Journal of Monetary Economics, 34, 297-323.

Nicodème, G. (2001), "Computing effective corporate tax rates: comparisons and results", Directorate General for Economic and Financial Affairs Economic Paper, No.153. <https://ec.europa.eu/economy_finance/publications/pages/publication942_en.pdf>, 29.11.2021.

OECD (1991), “Taxing Profits in a Global Economy: Domestic and International Issues", Working Paper No. 2, Tax Analysis and Tax Statistics of the Committee on Fiscal Affairs, Paris: OECD Publication.

OECD (2000), “Tax Burdens: Alternative Measures”, OECD Tax Policy Studies, 2. Paris: OECD Publication.

Papageorgiou, D. et al. (2012), "Effective Tax Rates in Greece”, Centre for Planning and Economic Research Discussion Papers, Discussion Papers no. 124.

Simon, H. \& M. Harding (2020), "What Drives Consumption Tax Revenues? Disentangling Policy and Macroeconomic Drivers", OECD Taxation Working Papers, No: 47.

Sørensen, P.B. (2004), "Measuring Taxes on Capital and Labor: An Overview of Methods and Issues", in: P.B. Sørensen (ed), Measuring Taxes on Capital and Labor (1-33), CESifo Seminer Series, London: The MIT Press.

Sosyal Güvenlik Kurumu (2020), Sosyal Güvenlik Prim Gelirleri 2006-2010, <http://www.sgk.gov.tr/wps/portal/sgk/tr/kurumsal/istatistik>, 10.12.2020.

TÜİK (2020a), Gelir Yöntemiyle Hesaplanmış Gayri Safi Yurtiçi Hâsıla, <http://www.tuik.gov.tr/>, 15.12.2020.

TÜİK (2020b), Harcamalar Yöntemiyle Hesaplanmış Gayri Safi Yurtiçi Hâsıla, $<$ http://www.tuik.gov.tr/>, 10.12.2020.

TÜİK (2020c), Büyüme Oranlarl, <http://www.tuik.gov.tr/>, 15.12.2020.

TÜİK (2020d), İssizlik Oranları, <http://www.tuik.gov.tr/>, 15.12.2020.

Türkiye İş Kurumu (2020), İssizlik Sigortası Fonu Prim Gelirleri, <https://www.iskur.gov.tr/kurumsal-bilgi/istatistikler/>, 12.12.2020.

Ünlükaplan, İ. \& İ. Arısoy (2011), “Türkiye Ekonomisi İçin Efektif Vergi Oranlarının Hesaplanması”, Ege Akademik Bakış, 11(1), 15-24.

Volkerink B. \& J. De Haan (2001), "Tax Ratios: A Critical Survey”, Tax Policy Studies, 5.

Volkerink B. et al. (2002), “Tax Ratios in Macroeconomics. Do Taxes Really Matter ?”, Empirica, 29, 209-224. 